\title{
Effects of reducing dietary cation-anion difference on lactation performance and nutrient digestibility of lactating cows and ammonia emissions from manure
}

\author{
H. M. Zynda, ${ }^{1} \odot$ J. E. Copelin, ${ }^{1} \oplus$ W. P. Weiss, ${ }^{1} \oplus$ F. Sun, ${ }^{2} \odot$ and C. Lee ${ }^{1 *} \oplus$ \\ ${ }^{1}$ Department of Animal Sciences, Ohio Agricultural Research and Development Center, The Ohio State University, Wooster 44691 \\ ${ }^{2}$ Origination LLC, Woodbury, MN 55125
}

\begin{abstract}
Reducing the dietary cation-anion difference (DCAD) reduces urine $\mathrm{pH}$ and, therefore, has potential to lower $\mathrm{NH}_{3}$ emissions from manure. We determined the effects of decreased DCAD on dry matter intake, production, nutrient digestibility, manure characteristics, and $\mathrm{NH}_{3}$ emissions from manure. An in vitro incubation study was conducted to evaluate the degree of reduced urine $\mathrm{pH}$ on manure $\mathrm{pH}$ and $\mathrm{NH}_{3}$ emissions from manure. In this study, urine $\mathrm{pH}$ was directly decreased from 8.5 to $7.5,6.5$, and 5.5 by adding sulfuric acid, which resulted in decreases in manure $\mathrm{pH}$ when manure was reconstituted with the fecal-to-urine ratio of 2:1 (as-is basis). The manures from urine at $\mathrm{pH} 7.5,6.5$, and 5.5 decreased $\mathrm{NH}_{3}$ emissions linearly by 19,33 , and $36 \%$, respectively, compared with the manure from unacidified urine. An animal study was conducted with 27 mid-lactation Holstein cows in a randomized complete block design. Cows were blocked by parity and days in milk and assigned to 1 of 3 different DCAD diets: (1) HDCAD, a diet with DCAD of $193 \mathrm{mEq} / \mathrm{kg}$ of dry matter (DM); (2) MDCAD, a diet with $101 \mathrm{mEq} / \mathrm{kg}$ of DM; and (3) LDCAD, a diet with $1 \mathrm{mEq} / \mathrm{kg}$ of DM. A commercial anionic product (predominantly ammonium chloride) partly replaced urea, soybean meal, soyhulls, and corn grain in MDCAD and LDCAD to lower DCAD. The experiment lasted $7 \mathrm{wk}$ (1-wk covariate followed by 6 -wk data collection). Spot urine and fecal samples were collected for manure incubation. Data were analyzed using the MIXED procedure of SAS in a randomized block design. Dry matter intake and milk yield were not altered by treatments. No difference in milk fat content was observed among treatments, but fat yield tended to decrease linearly (1.00 to 0.86 $\mathrm{kg} / \mathrm{d}$ ) as DCAD decreased, resulting in a tendency for decreasing energy-corrected milk yield (35.1 to 32.7
\end{abstract}

Received August 23, 2021.

Accepted January 20, 2022

*Corresponding author: lee.7502@osu.edu $\mathrm{kg} / \mathrm{d}$ ). Milk protein content increased (3.00 to $3.14 \%$ ) as DCAD decreased, but milk protein yield was not affected. Total-tract digestibility of DM, organic matter, and neutral detergent fiber did not differ among treatments. Digestibility of crude protein tended to decrease as DCAD decreased. There was no difference in fecal and urine $\mathrm{N}$ excretion among treatments, but fecal $\mathrm{N}$ as proportion of $\mathrm{N}$ intake tended to increase as DCAD decreased. Urine $\mathrm{pH}$ decreased linearly from 8.42 for HDCAD to 8.11 and 6.41 for MDCAD and LDCAD, respectively, resulting in decreased manure $\mathrm{pH}(7.57,7.40$, and 6.96 for HDCAD, MDCAD, and LDCAD, respectively). The cumulative $\mathrm{NH}_{3}$ emissions from manures over $6 \mathrm{~d}$ tended to decrease linearly as DCAD decreased (461 to $390 \mathrm{mg} / \mathrm{kg}$ of manure), but the decrease was only numerical when calculated on a cow basis (i.e., g/cow). In conclusion, lowering DCAD has potential to reduce $\mathrm{NH}_{3}$ emission from manure of lactating cows. However, a tendency for decreased milk fat yield and energy-corrected milk yield suggests that DCAD of $1 \mathrm{mEq} / \mathrm{kg}$ of DM may be too low, and more studies are needed to examine relatively less reduced DCAD to determine production responses in addition to $\mathrm{NH}_{3}$ emission from manure.

Key words: ammonia, dietary cation-anion difference, manure, milk fat

\section{INTRODUCTION}

Reducing environmental impact has been an ongoing theme in animal feeding operations. Reducing manure $\mathrm{NH}_{3}$ is of interest because of its ability to form particulate matters (Hristov, 2011) that impairs air quality and poses respiratory risk for humans and animals. Further, local environmental effects of $\mathrm{NH}_{3}$ emission include water contamination and soil acidification from precipitation or leachate (Dennis et al., 2007). Proper manure management to reduce manure $\mathrm{NH}_{3}$ may need to start at the barn because losses can occur rapidly before the slurry enters a storage phase (Anderson et al., 2003; Mcllroy et al., 2019). The rate of $\mathrm{NH}_{3}$ emis- 
sion is affected by various environmental factors such as bedding type, air temperature, and humidity (Ndegwa et al., 2008; Bougouin et al., 2016). Likewise, inherent factors exist that may also accelerate or decelerate $\mathrm{NH}_{3}$ emission, such as manure characteristics (volume, $\mathrm{N}$ content, $\mathrm{pH}$ ). To decrease $\mathrm{NH}_{3}$ emissions, the effective strategies mainly involve processing manure when it has reached storage such as acidification, adding urease inhibitors, or covering manure (Chadwick, 2005; Fangueiro et al., 2015).

Diet manipulation can also reduce $\mathrm{NH}_{3}$ volatilization. Strategies such as reducing dietary protein (Lee et al., 2012; Zhang et al., 2019), shifting N excretion from urine to feces, or including corn dried distillers grains with solubles in a ration (Cole et al., 2008; Lee et al., 2020) were previously studied to reduce $\mathrm{NH}_{3}$ emissions from manure. Another potential strategy might be feeding a diet with reduced DCAD $(\mathrm{Na}+\mathrm{K}-\mathrm{Cl}-\mathrm{S})$ to lactating cows. Lactating cows are traditionally fed a diet with DCAD ranging from +150 to $300 \mathrm{mEq} /$ $\mathrm{kg}$ of $\mathrm{DM}$ when the diet meets mineral requirements (NRC, 2001). When cows were fed a diet with DCAD of 47 and $167 \mathrm{mEq} / \mathrm{kg}$ of $\mathrm{DM}(\mathrm{Na}+\mathrm{K}-\mathrm{Cl}$; the $\mathrm{S}$ content was not reported), West et al. (1991) observed urine $\mathrm{pH}$ of 6.6 and 7.4 , respectively, versus urine $\mathrm{pH}$ of 8.1 from cows fed DCAD of $324 \mathrm{mEq} / \mathrm{kg}$ of $\mathrm{DM}$ in a cool condition (temperature range during the experiment was $15.0-26.7^{\circ} \mathrm{C}$ ). Luebbe et al. (2011) fed lambs with DCAD of 0 and $80 \mathrm{mEq} / \mathrm{kg}$ of $\mathrm{DM}(\mathrm{Na}+$ $\mathrm{K}-\mathrm{Cl}-\mathrm{S}$ ) and recorded a urine $\mathrm{pH}$ of 7.47 and 7.90 compared with $\mathrm{pH} 8.45$ for lambs fed $400 \mathrm{mEq} / \mathrm{kg}$ of DM. If decreased urine $\mathrm{pH}$ can lower manure $\mathrm{pH}$, it has potential to reduce $\mathrm{NH}_{3}$ emissions from manure. However, feeding a low DCAD diet to lactating cows may negatively affect performance and nutrient digestibility. Dry matter intake, milk yield, milk fat yield, and NDF digestibility are performance characteristics positively associated with increasing DCAD in lactating cows from meta-analyses ( $\mathrm{Hu}$ and Murphy 2004; Iwaniuk and Erdman, 2015). However, when reduced DCAD was evaluated in some designed experiments, performance responses were not consistent and vary on a trial-to-trial basis. For example, Tucker et al. (1988) observed no difference in total milk or fat-corrected milk when DCAD increased from 0 to $200 \mathrm{mEq} / \mathrm{kg}$ of $\mathrm{DM}(\mathrm{Na}+\mathrm{K}-\mathrm{Cl}$; the $\mathrm{S}$ content was not reported). Additionally, Apper-Bossard et al. (2010) reported no linear or quadratic effect of DCAD on NDF digestibility as DCAD increased from 11 to $327 \mathrm{mEq} / \mathrm{kg}$ of DM.

The hypothesis of this study was that urine and manure $\mathrm{pH}$ would decrease when lactating cows are fed a reduced DCAD diet, which could decrease $\mathrm{NH}_{3}$ emission from manure. Furthermore, there might be a level of reduced DCAD that can reduce urine $\mathrm{pH}$ without negatively affecting performance and nutrient digestibility. The purpose of the in vitro study was to evaluate the concept that reducing urine $\mathrm{pH}$ can lower $\mathrm{NH}_{3}$ emission from manure and the objective of the animal study was to determine the effects of reducing DCAD on DMI, lactation performance, nutrient digestibility, and $\mathrm{NH}_{3}$ emission from manure.

\section{MATERIALS AND METHODS}

All procedures that involved animals were approved through The Ohio State University Institutional Animal Care and Use Committee (2019A00000095).

\section{In Vitro Incubation Study}

Sample Collection. Feces and urine were collected from 4 lactating Holstein cows at the Krauss Dairy Center (The Ohio State University, Wooster) by catching feces during a natural defecation event or directly from the rectum and urine after gentle massage of the vulva at about $3 \mathrm{~h}$ before feeding. Approximately $2 \mathrm{~kg}$ of both feces and urine from each cow was composited and thoroughly mixed for a total of $8 \mathrm{~kg}$ of feces and $8 \mathrm{~kg}$ of urine. The cows used for collection were fed a diet $(16.5 \% \mathrm{CP}$ and about $250 \mathrm{mEq} / \mathrm{kg}$ of $\mathrm{DM}$ of DCAD) containing $36 \%$ corn silage, $18 \%$ alfalfa silage, $14 \%$ ground corn grain, $11 \%$ AminoPlus (Ag Processing Inc.), $8 \%$ wheat middlings, $2.5 \%$ molasses (Omalass, Westway Feed Products LLC), 4\% soyhulls, $2 \%$ Megalac (Church \& Dwight Co. Inc.), $0.18 \%$ urea, and a vitamin-mineral mix (DM basis).

After collection, urine was filtered through 2-layers of cheesecloth and separated equally by weight into 4 subsamples. The $\mathrm{pH}$ of 1 aliquot of urine was recorded and considered to be the control of unaltered urine $\mathrm{pH}$ ( $\mathrm{pH}$ of 8.5). Using $95 \%$ reagent-grade $\mathrm{H}_{2} \mathrm{SO}_{4}$ (Fisher Chemical), the other urine aliquots were reduced to $\mathrm{pH}$ of $7.5,6.5$, or 5.5. Distilled water, acid, or a combination of water and acid was added to the aliquots to equalize the volume added across treatments. Only distilled water was added to the control urine (i.e., $\mathrm{pH}$ 8.5).

Manure Incubation. Urine prepared at various $\mathrm{pH}$ were mixed with feces in a ratio of $2: 1$ to mimic the average fecal and urine outputs of Holsteins that were observed from the total collection trials (Weiss et al., 2009). Each treatment was assigned in quadruplicate to 16 chambers randomly. Each chamber $(3.8 \mathrm{~L})$ contained $500 \mathrm{~g}$ of manure: $333 \mathrm{~g}$ of feces and $167 \mathrm{~g}$ of urine. Feces and manure were subsampled and measured for pH (Van Baale et al., 2004). Manures were incubated for $5 \mathrm{~d}$ in a continuous air flux multichamber system (Wheeler et al., 2011; Lee et al., 2020) and monitored 
$\mathrm{NH}_{3}$ emissions. Briefly, air flow from pumps (DDL 15101, Gast Manufacturing) traveled to an inlet port of a $600-\mathrm{mL}$ jar containing $300 \mathrm{~mL}$ of water. An exhaust line from the water jars carried air plus water vapors (to avoid rapid dryness of manure surface) to the 3.8 L chambers containing manure. Each chamber had an exhaust line flowing from the chambers to the hood fan and a separate sampling line was connected to the exhaust line of each chamber and led to gas sampling pumps. The gas sampling pump (KPM27H; Koge Electronics Co. Ltd.) attached to each sampling line was programmed to collect gas for $30 \mathrm{~s}$ every $30 \mathrm{~min}$ for $24 \mathrm{~h}$ in a gas sampling bag (12-L multilayer foil gas sampling bag, Restek). The sampling bags were replaced every $24 \mathrm{~h}$ over the course of the 5 -d incubation, providing 5 samples per chamber. A photoacoustic gas analyzer (detection range of $\mathrm{NH}_{3}, 0.1$ to 5,000 ppm; Gasera One, Gasera Ltd.) was used to analyze $\mathrm{NH}_{3}$ concentration in the sampling bag. In the system, there was 1 blank chamber (i.e., chamber without manure) to correct for ambient $\mathrm{NH}_{3}$. Full calculations for conversion to $\mathrm{NH}_{3}$ mass emission can be found in Lee et al. (2020). Briefly, the $\mathrm{NH}_{3}$ concentration in daily gas sample was multiplied by the daily air flux $(2 \mathrm{~L} / \mathrm{min})$ and 1,440 min and adjusted to convert volume to mass with $\mathrm{NH}_{3}$ density of $0.769 \mathrm{~g} / \mathrm{L}$ at the standard condition for temperature and pressure.

\section{Statistical Analysis.}

Data were analyzed using the MIXED procedure of SAS (version 9.4, SAS Institute Inc.). Treatment, day of incubation, and treatment by day interaction were fixed effects. Days of incubation were included as repeated measures with covariance structures [autoregressive (1), compound symmetry, or unstructured] selected based on the smallest Akaike information criterion. The same model was used for cumulative $\mathrm{NH}_{3}$ emission except that the time effect was removed. Treatment comparison was performed using orthogonal polynomial contrasts (i.e., linear, quadratic, and cubic effect). Significance was determined at $P \leq 0.05$ and trends were considered when $0.05<P \leq 0.10$.

\section{Animal Study.}

Experimental Design, Cows, and Treatments Twenty-seven lactating Holstein cows (average \pm SD; $95 \pm 17$ DIM, $44 \pm 9 \mathrm{~kg} / \mathrm{d}$ milk yield, $664 \pm 67 \mathrm{~kg} \mathrm{BW})$ were used in this experiment from July to September 2020. Total duration of the study included 1 wk as covariate followed by $6 \mathrm{wk}$ of data collection. Cows were blocked by parity and DIM in a randomized complete block design, with 3 blocks of primiparous and 6 blocks of multiparous cows. Cows in each block were randomly assigned to the following formulated DCAD treatments: (1) HDCAD, $200 \mathrm{mEq} / \mathrm{kg}$ of DM; (2) MDCAD, 100 $\mathrm{mEq} / \mathrm{kg}$ of DM; (3) LDCAD, $10 \mathrm{mEq} / \mathrm{kg}$ of DM. The level of $10 \mathrm{mEq} / \mathrm{kg}$ of DM for LDCAD was selected because we wanted to evaluate DCAD that is close to 0 but not negative to decrease urine $\mathrm{pH}$ as low as possible with minimal effects on performance. After consideration of potential variability between formulated and actual DCAD, $10 \mathrm{mEq} / \mathrm{kg}$ of DM for LDCAD was selected. Indeed, actual DCAD after feed analysis was 193, 101, and $1 \mathrm{mEq} / \mathrm{kg}$ of DM for HDCAD, MDCAD, and LDCAD, respectively. Furthermore, $10 \mathrm{mEq} / \mathrm{kg}$ of DM of DCAD for LDCAD was chosen based on our previous study (Lee et al., 2020) where urine $\mathrm{pH}$ was reduced from 8.53 to 7.48 when DCAD decreased from 195 to $65 \mathrm{mEq} / \mathrm{kg}$ of DM. All diets were formulated to be isonitrogenous and to meet or exceed all nutrient requirements of lactating cows $(25 \mathrm{~kg} / \mathrm{d}$ of DMI, $40 \mathrm{~kg} / \mathrm{d}$ of milk yield, $650 \mathrm{~kg}$ of BW) according to NRC (2001) and shown in Table 1. To decrease DCAD for MDCAD and LDCAD, a commercially available DCAD product (mainly ammonium chloride; MegAnion, Origination LLC; CP, 81.5\%; CP from NPN, 53.5\%; Na, 0.07\%; K, $1.15 \%$; Cl, 23.69\%; S, 3.08\%; DCAD, $-8,275 \mathrm{mEq} / \mathrm{kg}$ on a DM basis) was included in the ration by partly replacing soybean meal, soyhulls, corn grain, and urea to account for CP content and NPN. Cows were fed once daily at $0600 \mathrm{~h}$ with free access to water and milked twice daily at 0400 and $1600 \mathrm{~h}$. Feed was offered for ad libitum intake with a target of $3 \%$ refusal. Cows were weighed on 2 consecutive days at the ends of the covariate (wk 1) and experiment (wk 6).

\section{Sample Collection and Analyses}

Refusals were weighed daily, and subsamples were collected twice weekly and composited by volume within wk for each cow and analyzed for $55^{\circ} \mathrm{C}$ DM. Forages and concentrates were sampled weekly and composited by month for analysis. Forages were dried at $55^{\circ} \mathrm{C}$ for $72 \mathrm{~h}$ to determine DM. Dried forages and concentrates were ground (Wiley Mill; Arthur H. Thomas Co.) to pass through a $1-\mathrm{mm}$ sieve. The ground feed samples were dried at $100^{\circ} \mathrm{C}$ for $24 \mathrm{~h}$ to determine $\mathrm{DM}$ and then analyzed for $\mathrm{OM}$ in a $600^{\circ} \mathrm{C}$ ash oven for $8 \mathrm{~h}$ (methods 22.008 and 22.010; AOAC International, 2000). Each feed was weighed into filter bags with a pore size of $25 \mu \mathrm{m}$ (Ankom Technology Corp.) and analyzed for NDF using heat-stable $\alpha$-amylase and sodium sulfite (Van Soest et al., 1991). Ground samples were used to reconstitute each TMR and analyzed for fatty acids (FA) using the method described by Jenkins (2010). Corn silage and concentrate samples were analyzed for 
starch content according to Holm et al. (1986). All forage and concentrate samples were sent to a commercial laboratory (Rock River Laboratory Inc., Watertown, WI) for macrominerals analysis $(\mathrm{Ca}, \mathrm{P}, \mathrm{K}, \mathrm{Mg}, \mathrm{S}, \mathrm{Na}$, and $\mathrm{Cl}$ ) with inductively coupled plasma spectrometry. Feed $\mathrm{N}$ was measured by combustion (Morris et al., 2019; Elemental Analyzer; Flash 2000; Thermo Fisher

Table 1. Ingredient and chemical composition of diets with high, intermediate, and low DCAD fed during Experiment 2

\begin{tabular}{|c|c|c|c|}
\hline \multirow[b]{2}{*}{ Item } & \multicolumn{3}{|c|}{ DCAD $^{1}$} \\
\hline & HDCAD & MDCAD & LDCAD \\
\hline \multicolumn{4}{|l|}{ Ingredient, $\%$ of DM } \\
\hline Corn silage $^{2}$ & 53.1 & 53.1 & 53.1 \\
\hline Alfalfa silage $^{3}$ & 6.62 & 6.62 & 6.62 \\
\hline Corn grain, ground & 9.68 & 9.43 & 9.18 \\
\hline Soybean meal, $48 \%$ & 13.6 & 13.3 & 13.0 \\
\hline Urea & 0.48 & 0.24 & 0.00 \\
\hline MegAnion $^{4}$ & 0.00 & 1.16 & 2.32 \\
\hline Soyhulls & 11.0 & 10.8 & 10.6 \\
\hline Animal/vegetable fat ${ }^{5}$ & 2.31 & 2.31 & 2.31 \\
\hline Trace mineral salts ${ }^{6}$ & 0.70 & 0.70 & 0.70 \\
\hline Mineral-vitamin $\operatorname{mix}^{7}$ & 2.56 & 2.41 & 2.26 \\
\hline \multicolumn{4}{|c|}{ Chemical composition, \% of DM } \\
\hline $\mathrm{OM}$ & 93.4 & 93.7 & 93.4 \\
\hline $\mathrm{CP}$ & 16.3 & 16.2 & 16.2 \\
\hline NDF & 32.0 & 32.8 & 31.8 \\
\hline Fatty acids ${ }^{8}$ & 3.62 & 3.69 & 3.51 \\
\hline C16:0 & 17.9 & 17.4 & 17.7 \\
\hline C18:0 & 4.84 & 4.76 & 4.60 \\
\hline C18:1, cis-9 & 23.8 & 23.53 & 23.6 \\
\hline C18:1, cis-11 & 1.72 & 1.73 & 1.76 \\
\hline C18:2n-6 & 32.4 & 33.7 & 33.0 \\
\hline C18:3n-3 & 4.41 & 4.46 & 4.54 \\
\hline Starch & 26.9 & 26.2 & 26.2 \\
\hline $\mathrm{Ca}$ & 0.80 & 0.82 & 0.81 \\
\hline $\mathrm{P}$ & 0.36 & 0.37 & 0.37 \\
\hline $\mathrm{Mg}$ & 0.23 & 0.23 & 0.23 \\
\hline $\mathrm{Na}$ & 0.30 & 0.28 & 0.31 \\
\hline $\mathrm{K}$ & 1.29 & 1.28 & 1.27 \\
\hline $\mathrm{Cl}$ & 0.55 & 0.81 & 1.21 \\
\hline $\mathrm{S}$ & 0.18 & 0.19 & 0.19 \\
\hline $\mathrm{DCAD},{ }^{9} \mathrm{mEq} / \mathrm{kg}$ of $\mathrm{DM}$ & 193 & 101 & 1 \\
\hline
\end{tabular}

${ }^{1} \mathrm{HDCAD}=193 \mathrm{mEq} / \mathrm{kg}$ of DM; MDCAD $=101 \mathrm{mEq} / \mathrm{kg}$ of $\mathrm{DM}$; $\mathrm{LDCAD}=1 \mathrm{mEq} / \mathrm{kg}$ of DM.

${ }^{2} \mathrm{CP}=6.8 \%, \mathrm{NDF}=35 \%$, starch $=36 \%$ (DM basis).

${ }^{3} \mathrm{CP}=19 \%, \mathrm{NDF}=42 \%$ (DM basis).

${ }^{4}$ Origination LLC (DM basis; CP, $81.5 \%$; CP from NPN, $53.5 \%$; Na, $0.07 \%$; K, 1.15\%; Cl, 23.69\%; S, 3.08\%; DCAD, $-8,275 \mathrm{mEq} / \mathrm{kg}$ ).

${ }^{5}$ True energy formula (20\% palmitic and stearic acids, $34 \%$ oleic acid, $38 \%$ linoleic acid); G. A. Wintzer and Son Co.

${ }^{6}$ The mix contains (as-is basis): $39.3 \%$ sodium, $53.2 \%$ chloride, $70 \mathrm{mg} /$ $\mathrm{kg}$ cobalt, $400 \mathrm{mg} / \mathrm{kg}$ copper, $70 \mathrm{mg} / \mathrm{kg}$ iodine, $1,750 \mathrm{mg} / \mathrm{kg}$ iron, $2,800 \mathrm{mg} / \mathrm{kg}$ manganese, $200 \mathrm{mg} / \mathrm{kg}$ Se, and 3,500 $\mathrm{mg} / \mathrm{kg}$ zinc.

${ }^{7}$ The mix contains (DM basis): $49.84 \%$ limestone, $4.98 \%$ selenium premix $(200 \mathrm{mg} / \mathrm{kg}$ of selenium as sodium selenite; Vita Vet Labs, Marion IN), $9.90 \%$ potassium sulfate, $2.16 \%$ vitamin E, $0.50 \%$ vitamin A, $1.66 \%$ vitamin $\mathrm{D}, 24.92 \%$ dicalcium phosphate, $0.04 \%$ copper sulfate, $3.18 \%$ magnesium sulfate, $2.62 \%$ magnesium oxide, and $0.21 \%$ zinc sulfate.

${ }^{8}$ Individual fatty acids reported on a percent of total fatty acids basis. ${ }^{9} \mathrm{DCAD}(\mathrm{mEq} / \mathrm{kg}$ of $\mathrm{DM})=(\mathrm{Na}+\mathrm{K})-(\mathrm{Cl}+\mathrm{S})$, where the unit of $\mathrm{Na}, \mathrm{K}, \mathrm{Cl}$, and $\mathrm{S}$ is $\mathrm{mEq} / \mathrm{kg}$ of DM.
Scientific). Total mixed rations were reconstituted from fresh forage and grain samples taken during wk 6 . Particle separation using Pennsylvania State Particle Separator (Kononoff et al., 2003) was performed on all wk-6 refusals and reconstituted TMR.

Milk samples were taken on d 5 and 6 of each week during the entire experiment period (morning of afternoon of each day) and sent to DHIA (Columbus, $\mathrm{OH}$ ) to measure milk fat, true protein, lactose (2000 infrared analyzer, Bentley Instruments). Additional a.m. and p.m. milk samples were collected on d 6 of wk 6 and proportionally composited by morning and afternoon milk weights. The composite milk was centrifuged $\left(20,000 \times g\right.$ for $30 \mathrm{~min}$ at $\left.4^{\circ} \mathrm{C}\right)$ to separate the milk fat, and the milk fat was frozen for further analysis of FA composition according to Jenkins (2010).

Blood samples were drawn via coccygeal venipuncture into evacuated lithium heparin tubes on $\mathrm{d} 1$ of wk 6 at $4 \mathrm{~h}$ after feeding. The samples were immediately centrifuged $\left(3,000 \times g\right.$ for $15 \mathrm{~min}$ at $\left.4^{\circ} \mathrm{C}\right)$, and the plasma transferred into microtubules for storage at $-20^{\circ} \mathrm{C}$ until further analysis for urea $\mathrm{N}$ concentration (kit UR107, Randox Laboratories Ltd.).

To monitor urine $\mathrm{pH}$ during the experiment, spot urine was sampled weekly at about $4 \mathrm{~h}$ after feeding by massaging the vulva and immediately measured for pH (Accumet AE150; Fisher Scientific). To estimate fecal and urine outputs and nutrient digestibility, spot fecal and urine samples were collected over $3 \mathrm{~d}$ during the last week of the experiment. Six spot samples from individual cows representing every $4 \mathrm{~h}$ in a 24 -h period were collected (Morris et al., 2018c; Lee et al., 2019), at 0600 and $1800 \mathrm{~h}$ on d 1, 0200 and $1400 \mathrm{~h}$ on $\mathrm{d} \mathrm{2}$, and 1000 and $2200 \mathrm{~h}$ on d 3. Each spot sample was kept in a freezer immediately after sampling to minimize $\mathrm{N}$ losses. Spot fecal samples were obtained from the rectum and composited per cow. Approximately $1 \mathrm{~kg}$ of each composite was frozen until manure incubation. A subsample of each composite feces was dried at $55^{\circ} \mathrm{C}$ for $72 \mathrm{~h}$ to determine DM content. Dried composite fecal samples were ground (Wiley mill; Arthur H. Thomas Co.) to pass through a 1-mm sieve. The ground fecal samples were dried at $100^{\circ} \mathrm{C}$ for $24 \mathrm{~h}$ to determine DM and further analyzed for OM, NDF (Ankom Technology Corp.), and $\mathrm{N}$ as described for feeds. Indigestible neutral detergent fiber (iNDF) of the ground fecal samples was determined by incubating samples in the rumen for $12 \mathrm{~d}$ using 2 cannulated cows (Huhtanen et al., 1994) and then assaying for NDF of the residuals. The content of iNDF was used as an internal marker to estimate fecal output (Morris et al., 2018b). To calculate the digestibility of nutrients, nutrient intakes were obtained from DMI and nutrient concentrations (OM, $\mathrm{CP}$, and $\mathrm{NDF}$ ) of the diets collected during the fecal 
Table 2. Effect of DCAD on nutrient intake and digestibility in Experiment 2

\begin{tabular}{|c|c|c|c|c|c|c|}
\hline \multirow[b]{2}{*}{ Item } & \multicolumn{3}{|c|}{ DCAD $^{1,2}$} & \multirow[b]{2}{*}{ SEM } & \multicolumn{2}{|c|}{$P$-value ${ }^{3}$} \\
\hline & HDCAD & MDCAD & LDCAD & & $\mathrm{L}$ & $\mathrm{Q}$ \\
\hline \multicolumn{7}{|c|}{ Intake, $\mathrm{kg} / \mathrm{d}$} \\
\hline DM & 23.2 & 22.3 & 22.0 & 1.18 & 0.34 & 0.80 \\
\hline $\mathrm{OM}$ & 21.7 & 20.9 & 20.6 & 1.10 & 0.34 & 0.86 \\
\hline $\mathrm{NDF}$ & 7.52 & 7.40 & 7.08 & 0.385 & 0.29 & 0.78 \\
\hline $\mathrm{CP}$ & 3.68 & 3.52 & 3.47 & 0.187 & 0.29 & 0.75 \\
\hline \multicolumn{7}{|c|}{ Digestibility, \% } \\
\hline DM & 65.7 & 65.6 & 65.3 & 0.55 & 0.58 & 0.91 \\
\hline $\mathrm{OM}$ & 66.9 & 67.1 & 66.5 & 0.53 & 0.62 & 0.60 \\
\hline NDF & 37.1 & 38.9 & 38.2 & 1.73 & 0.66 & 0.53 \\
\hline $\mathrm{CP}$ & 68.4 & 67.6 & 66.3 & 0.85 & 0.09 & 0.80 \\
\hline
\end{tabular}

${ }^{1} \mathrm{HDCAD}=193 \mathrm{mEq} / \mathrm{kg}$ of DM; MDCAD $=101 \mathrm{mEq} / \mathrm{kg}$ of DM; LDCAD = $1 \mathrm{mEq} / \mathrm{kg}$ of DM.

${ }^{2}$ Diet samples during the fecal sampling (wk 6) were analyzed and used for nutrient intakes and digestibility: $\mathrm{OM}=93.5,93.8$, and $93.5 \% ; \mathrm{CP}=15.9,15.8$, and $15.8 \% ; \mathrm{NDF}=32.4,33.2$, and $32.2 \%$ for HDCAD, MDCAD, and LDCAD, respectively (DM basis).

${ }^{3} \mathrm{~L}=$ linear, $\mathrm{Q}=$ quadratic effect of dietary DCAD.

sampling (wk 6; see a footnote for composition in Table 2 ). An aliquot of urine at each sampling time point was composited by cow and frozen until manure incubation. Another aliquot of each urine sample was composited, acidified using $2 \mathrm{M} \mathrm{H}_{2} \mathrm{SO}_{4}$, and frozen until further chemical analysis. Total $\mathrm{N}$ was determined according to the procedure by Morris et al. (2019). Urinary creatinine concentration was assayed (kit 500701; Cayman Chemical) and used to estimate total urinary output. Urinary output was estimated by assuming a constant of $29 \mathrm{mg}$ of creatinine (Valadares et al., 1999; Tebbe and Weiss, 2018) excreted in urine for every $\mathrm{kg}$ of BW.
Nitrogen intakes for individual cows to calculate $\mathrm{N}$ excretions as proportion of $\mathrm{N}$ intake and $\mathrm{N}$ balance were obtained from DMI and CP content of the diets during the fecal and urine sampling (wk 6; see footnote for CP content in Table 3). Urine urea $\mathrm{N}$ was assayed using a commercial assay kit (kit UR107, Randox Laboratories Ltd.).

\section{Manure Characteristics and Incubation}

Feces and urine collected from individual cows were thawed and mixed in a ratio calculated from total fecal

Table 3. Effect of DCAD on nitrogen excretion and retention in Experiment 2

\begin{tabular}{|c|c|c|c|c|c|c|}
\hline \multirow[b]{2}{*}{ Item } & \multicolumn{3}{|c|}{$\mathrm{DCAD}^{1,2}$} & \multirow[b]{2}{*}{ SEM } & \multicolumn{2}{|c|}{$P$-value ${ }^{3}$} \\
\hline & HDCAD & MDCAD & LDCAD & & $\mathrm{L}$ & $\mathrm{Q}$ \\
\hline $\mathrm{N}$ intake, $\mathrm{g} / \mathrm{d}$ & 589 & 563 & 555 & 30.0 & 0.29 & 0.75 \\
\hline $\mathrm{PUN},{ }^{4} \mathrm{mg} / \mathrm{dL}$ & 16.9 & 15.6 & 17.1 & 1.10 & 0.92 & 0.29 \\
\hline \multicolumn{7}{|l|}{ Feces } \\
\hline $\mathrm{N}, \mathrm{g} / \mathrm{d}$ & 186 & 183 & 188 & 11.2 & 0.93 & 0.70 \\
\hline $\mathrm{N}, \%$ of $\mathrm{N}$ intake & 31.6 & 32.4 & 33.7 & 0.85 & 0.09 & 0.80 \\
\hline \multicolumn{7}{|l|}{ Urine } \\
\hline $\mathrm{N}, \mathrm{g} / \mathrm{d}$ & 153 & 143 & 147 & 8.0 & 0.47 & 0.34 \\
\hline Urea $\mathrm{N}, \mathrm{g} / \mathrm{d}$ & 83.8 & 71.4 & 80.3 & 6.77 & 0.68 & 0.15 \\
\hline $\mathrm{N}, \%$ of $\mathrm{N}$ intake & 26.0 & 25.5 & 26.7 & 0.71 & 0.50 & 0.53 \\
\hline \multicolumn{7}{|l|}{ Milk } \\
\hline Protein N, g/d & 190 & 187 & 183 & 10.5 & 0.49 & 0.94 \\
\hline Protein N, \% of N intake & 32.4 & 33.3 & 33.0 & 1.12 & 0.63 & 0.60 \\
\hline Manure ${ }^{5}, \mathrm{~g} / \mathrm{d}$ & 339 & 326 & 335 & 18.1 & 0.81 & 0.50 \\
\hline Total $\mathrm{N}$ output, $\mathrm{g} / \mathrm{d}$ & 529 & 513 & 518 & 26.9 & 0.66 & 0.65 \\
\hline $\mathrm{N}$ balance, $\mathrm{g} / \mathrm{d}$ & 59.9 & 49.8 & 37.3 & 8.86 & 0.09 & 0.91 \\
\hline $\mathrm{N}$ balance, $\%$ of $\mathrm{N}$ intake & 10.0 & 8.8 & 6.6 & 1.41 & 0.09 & 0.78 \\
\hline
\end{tabular}

${ }^{1} \mathrm{HDCAD}=193 \mathrm{mEq} / \mathrm{kg}$ DM; MDCAD = $101 \mathrm{mEq} / \mathrm{kg}$ DM; LDCAD = $1 \mathrm{mEq} / \mathrm{kg}$ DM.

${ }^{2}$ Diet samples during the fecal and urine sampling (wk 6) were analyzed and used for nutrient intakes and digestibility: $\mathrm{CP}=15.9,15.8$, and $15.8 \%$ for HDCAD, MDCAD, and LDCAD, respectively (DM basis).

${ }^{3} \mathrm{~L}=$ linear, $\mathrm{Q}=$ quadratic effect of dietary DCAD.

${ }^{4}$ Plasma urea nitrogen.

${ }^{5}$ Calculated values from urine and feces $\mathrm{N}$. 
(estimated from iNDF) and urine output (estimated from creatinine excretion). A subsample of each of the urine, feces, and manure was assayed for $\mathrm{pH}$ (Van Baale et al., 2004). Manure was also assayed for $\mathrm{TS}\left(100^{\circ} \mathrm{C}\right.$ for $24 \mathrm{~h}$ ) and volatile solids (\% of DM; $600^{\circ} \mathrm{C}$ for $8 \mathrm{~h}$; adapted from methods 22.008 and 22.010; AOAC International, 2000). After manure incubation, each manure was sampled and assayed for $\mathrm{pH}$ as described previously. Five hundred grams of each manure was incubated for $6 \mathrm{~d}$ to monitor $\mathrm{NH}_{3}$ emissions as described in the in vitro incubation study. There were 2 separate incubation periods due to the number of chambers available (16 chambers +1 blank chamber in the incubation system). In the first incubation, manures from first 5 cow blocks were placed randomly in 15 chambers. The second incubation included 12 chambers from the final 4 cow blocks of manures. A cow-basis $\mathrm{NH}_{3}$ emission was calculated by multiplying daily $\mathrm{NH}_{3}$ emission by estimated manure output.

\section{Statistical Analyses}

Statistical analyses were performed using the PROC MIXED model of SAS (Version 9.4, SAS Institute). The following model was used to analyze the dependent variables of DMI, milk production and milk components:

$$
Y_{j k l}=\mu+\beta\left(X_{i}-\bar{X}\right)+D_{j}+b_{k}+W_{l}+(D W)_{j l}+e_{j k l} .
$$

where $Y_{j k l}$ is the dependent variable, $\mu$ is the overall mean, $\beta\left(X_{i}-\bar{X}\right)$ is the corresponding covariate variable, $D_{j}(j=1$ to 3$)$ was the fixed effect of the $j$ th dietary treatment, $b_{k}(k=1$ to 9$)$ was the random effect of the $k$ th block, $W_{l}(l=1$ to 6$)$ was the fixed effect and repeated measure of lth week, $(D W)_{j l}$ was the fixed interaction of the $j$ th diet in the $l$ th week, and $e_{j k l}$ was the random error. Covariance structure [autoregressive (1), compound symmetry, or unstructured] was selected based on the smallest Akaike information criterion. Week of experiment was the repeated unit for DMI, milk production, and component production. For data of $\mathrm{NH}_{3}$ emission, the same model was used except that week was replaced by day as the repeated measure and the covariate was removed. Initially, the model for $\mathrm{NH}_{3}$ emission included the terms of incubation, incubation $\times$ time, incubation $\times$ treatment, incubation $\times$ time $\times$ treatment as fixed effects and block nested within incubation as a random effect because 2 sets of manure incubation was conducted. However, the inclusion of incubation and its interactions were not significant $(P>$ 0.05 ) and were removed from the model. All other variables (i.e., particle size, milk FA, nutrient digestibility, manure characteristics, cumulative $\mathrm{NH}_{3}$ emission) used a model similar with the one above but it did not include covariate, time, and interaction between time and treatment in the model. Orthogonal polynomial contrasts (i.e., linear and quadratic effect) were used to compare treatments. Significance was determined at $P \leq 0.05$ and trends were considered when $0.05<P \leq 0.10$.

\section{RESULTS}

\section{In Vitro Incubation Study}

As treatments, urine $\mathrm{pH}$ was reduced from 8.5 to 7.5 , 6.5 , or 5.5 , but fecal $\mathrm{pH}$ (6.3) was the same across the treatments (Table 4). Reconstituting manures resulted in $\mathrm{pH}$ of $7.74,7.53,7.12$, and 6.93 for manures with urine $\mathrm{pH}$ of $8.5,7.5,6.5$, and 5.5 , respectively. Cumulative $\mathrm{NH}_{3}$ emissions over $5 \mathrm{~d}$ of incubation also linearly decreased (494 to $315 \mathrm{mg} ; P<0.01$ ) as urine $\mathrm{pH}$ decreased. Daily $\mathrm{NH}_{3}$ emissions were linearly decreased (98.8 to $63.1 \mathrm{mg} / \mathrm{kg}$ per day; $P<0.01$ ) as urine $\mathrm{pH}$ decreased (Figure 1). Day effect was significant $(P<$ $0.01)$ and an interaction of day by urine $\mathrm{pH}$ tended to be present $(P=0.08)$.

\section{Animal Study}

The particle size distributions of TMR and refusals were similar among treatments (Table 5), but the size

Table 4. Effect of manual acidification of urine with concentrated sulfuric acid on manure characteristics in Experiment 1

\begin{tabular}{|c|c|c|c|c|c|c|c|c|}
\hline Item & \multicolumn{4}{|c|}{ Urine $\mathrm{pH}^{1}$} & SEM & \multicolumn{3}{|c|}{$P$-value ${ }^{2}$} \\
\hline $\begin{array}{l}\text { Manure } \mathrm{pH}^{3} \\
\text { Cumulative } \mathrm{NH}_{3}, \mathrm{mg} / \mathrm{kg} \text { manure }\end{array}$ & $\begin{array}{l}7.74 \\
494\end{array}$ & $\begin{array}{l}7.53 \\
399\end{array}$ & $\begin{array}{ll}7.12 \\
332\end{array}$ & $\begin{array}{ll}6.93 \\
315\end{array}$ & 31.8 & $<0.01$ & 0.21 & 0.87 \\
\hline
\end{tabular}

${ }^{1} 8.5=$ urine $\mathrm{pH}$ without acid addition; 7.5, 6.5, $5.5=$ urine $\mathrm{pH}$ reduced by adding $\mathrm{H}_{2} \mathrm{SO}_{4}$.

${ }^{2} \mathrm{~L}=$ linear, $\mathrm{Q}=$ quadratic, $\mathrm{C}=$ cubic effect of urine $\mathrm{pH}$.

${ }^{3} \mathrm{Fecal} \mathrm{pH}=6.33$; the ratio of feces to urine $=2.0$ (as-is basis). 
Table 5. Particle size distribution (\% DM retained) of TMR and refusals at wk 6 as affected by varying DCAD in Experiment 2

\begin{tabular}{|c|c|c|c|c|c|c|}
\hline \multirow[b]{2}{*}{ Item } & \multicolumn{3}{|c|}{$\mathrm{DCAD}^{1}$} & \multirow[b]{2}{*}{ SEM } & \multicolumn{2}{|c|}{$P$-value ${ }^{2}$} \\
\hline & HDCAD & MDCAD & LDCAD & & $\mathrm{L}$ & $\mathrm{Q}$ \\
\hline \multicolumn{7}{|l|}{$\mathrm{TMR}, \mathrm{mm}$} \\
\hline$>18.0$ & 4.93 & 7.52 & 7.80 & & & \\
\hline 8.0 to 18.0 & 55.34 & 55.52 & 51.54 & & & \\
\hline 1.2 to 8.0 & 14.69 & 14.99 & 12.97 & & & \\
\hline$<1.2$ & 25.04 & 21.97 & 27.69 & & & \\
\hline \multicolumn{7}{|l|}{ Refusals, mm } \\
\hline$>18.0$ & 6.63 & 7.49 & 7.88 & 0.749 & 0.24 & 0.79 \\
\hline 8.0 to 18 & 62.78 & 60.13 & 63.81 & 1.37 & 0.60 & 0.07 \\
\hline 1.2 to 8.0 & 13.25 & 12.92 & 12.90 & 0.31 & 0.41 & 0.67 \\
\hline$<1.2$ & 17.34 & 19.46 & 15.41 & 1.68 & 0.44 & 0.15 \\
\hline
\end{tabular}

${ }^{1} \mathrm{HDCAD}=193 \mathrm{mEq} / \mathrm{kg}$ of DM; MDCAD $=101 \mathrm{mEq} / \mathrm{kg}$ of DM; LDCAD $=1 \mathrm{mEq} / \mathrm{kg}$ of DM.

${ }^{2} \mathrm{~L}=$ linear, $\mathrm{Q}=$ quadratic effect of dietary DCAD.

of 8.0 to $18.0 \mathrm{~mm}$ for refusals tended to be affected quadratically with MDCAD being lower than HDCAD and LDCAD.

Results of lactation performance are shown in Table 6. Dry matter intake and milk yield did not differ among treatments. Although milk fat concentration (on average $2.40 \%$ ) was not affected, milk fat yield tended to decrease linearly $(1.00$ to $0.86 \mathrm{~kg} / \mathrm{d} ; P=$ $0.08)$ as DCAD decreased, which, in turn, tended to reduce ECM linearly ( 35.1 to $32.7 \mathrm{~kg} / \mathrm{d} ; P=0.10)$ as well. Milk protein percent increased linearly $(P=0.03)$ as DCAD decreased, but milk protein yield was not affected by treatments. Lactose percent and yield were not different among treatments. No treatment $\times$ week interaction was found for production parameters.

The percentage of C18:2n-6 in milk FA increased linearly $(P=0.04)$, and C18:3n-3 also tended to increase linearly $(P=0.07)$ with decreasing DCAD (Table 7$)$. The concentration of trans-10,cis-12 C18:2 increased linearly $(P<0.01)$ as DCAD decreased. Therefore, total PUFA concentration also increased linearly $(P=$ $0.04)$ as DCAD decreased, whereas no difference was observed for SFA and MUFA. The concentration of trans-12 C18:1 was similar for HDCAD and MDCAD but greater for LDCAD, leading to quadratic responses $(P=0.01)$ as DCAD decreased. A quadratic response of cis-9 C18:1 $(P=0.03)$ and tendency for a quadratic response of cis-9,trans-11 C18:2 $(P=0.06)$ to DCAD levels were observed where the concentrations of those FA in milk were greatest for MDCAD and similar between HDCAD and LDCAD. All other FA did not differ among treatments. The sums of the FA $<\mathrm{C} 16$, $\mathrm{C} 16$, or $>\mathrm{C} 16$ were not affected by DCAD, and the concentration of odd- and branched-chain FA was similar among treatments.

During the last wk of the experiment, intake of DM, $\mathrm{OM}, \mathrm{CP}$, and NDF did not differ among treatments
(Table 2). Digestibility of DM, OM, and NDF did not differ, but digestibility of $\mathrm{CP}$ tended to decrease linearly $(P=0.09)$ with decreasing DCAD.

Nitrogen intake among treatments was not different (Table 3) and plasma urea $\mathrm{N}$ was not affected by DCAD levels. Fecal N excretion (g/d) did not differ among treatments, but fecal $\mathrm{N}$ excretion as a percent of $\mathrm{N}$ intake tended to increase (linear, $P=0.09$ ) with decreasing DCAD. Urine output of $\mathrm{N}$, urea $\mathrm{N}$ (g/d) and $\mathrm{N}$ as a percent of $\mathrm{N}$ intake was not different among treatments. Milk protein $\mathrm{N}$ secretion $(\mathrm{g} / \mathrm{d})$ and that as a percent of $\mathrm{N}$ intake were not affected by DCAD. Total $\mathrm{N}$ excretion did not differ among treatments. Nitrogen retained as a percent of intake

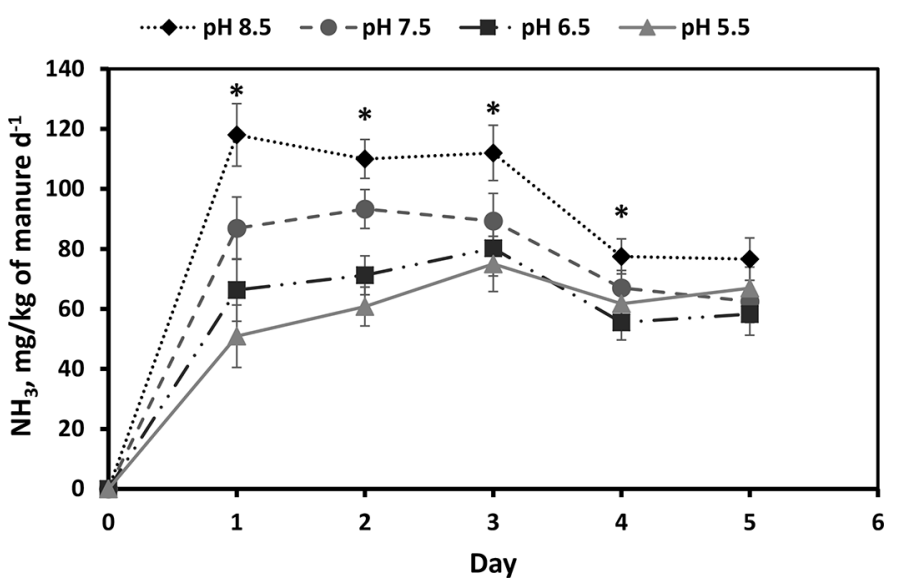

Figure 1. Effect of manual acidification on $\mathrm{NH}_{3}$ emission per kilogram of manure over 5-d incubation in the in vitro incubation study. $\mathrm{pH} 8.5=$ manure from urine of $\mathrm{pH} 8.5 ; \mathrm{pH} 7.5=$ manure from urine of $\mathrm{pH} 7.5 ; \mathrm{pH} 6.5=$ manure from urine of $\mathrm{pH} 6.5$; and $\mathrm{pH} 5.5=$ manure from urine of $\mathrm{pH}$ 5.5. Error bars indicate SEM. Linear effect, $P<$ 0.01 ; day effect, $P<0.01$; interaction of urine $\mathrm{pH}$ by day, $P=0.08$. * indicates linear effect $(P<0.05)$. 
and $\mathrm{g} / \mathrm{d}$ tended to decrease (linear $P=0.09$ ) with decreasing DCAD.

Weekly urine $\mathrm{pH}$ throughout the experiment had an interaction of DCAD by week $(P<0.01)$ and was lower for LDCAD compared with HDCAD and MDCAD (linear and quadratic $P<0.01$; Figure $2 \mathrm{~A}$ ). Urine $\mathrm{pH}$ within a 24 -h cycle had both linear $(P<0.01)$ and quadratic $(P<0.02)$ effects with decreasing DCAD (Figure 2B) with a tendency for an interaction of time by treatment $(P=0.10)$.

Fecal outputs (as-is basis) were not affected by treatments, and fecal pH did not differ (Table 8). Urine output was affected quadratically $(P=0.03)$ with LDCAD being greatest followed by HDCAD and MDCAD. Urine $\mathrm{pH}$ at time of sampling (8.42 to $6.41)$ and at start of the incubation (8.58 to 6.72$)$ was lower in a linear and quadratic fashion $(P<0.01)$ as DCAD decreased. Manure output was not affected by DCAD, but fecal-to-urine ratio tended to be affected quadratically $(P=0.08)$ with LDCAD being lowest followed by HDCAD and MDCAD. The ratio of fecal N to urine $\mathrm{N}$ was not affected by treatments. Manure $\mathrm{pH}$ was decreased (linear $P<0.01$ ) by DCAD before the incubation but was not different after a 6 -d incubation. Manure TS (\% of as-is) decreased linearly $(P=0.02)$ with decreasing DCAD, but volatile solids (\% of DM) were not affected. When $\mathrm{NH}_{3}$ emission was expressed as per kilogram of manure, the cumulative emission of $\mathrm{NH}_{3}$ tended to decrease linearly $(P=0.08)$ as DCAD decreased. However, the decrease was not apparent $(P$ $=0.16)$ when expressed as per cow. Similarly, no effect on cumulative $\mathrm{NH}_{3}$ emission was observed $(P \geq 0.11)$ when expressed as a percent of urine $\mathrm{N}$ and manure $\mathrm{N}$. The emission of $\mathrm{NH}_{3}$ over $6 \mathrm{~d}$ showed a day effect $(P<$ 0.01 ), but not a day $\times$ treatment interaction (Figure 3 ).

\section{DISCUSSION}

\section{In Vitro Incubation Study}

The purpose of the in vitro study was to evaluate the concept that reduced urine $\mathrm{pH}$ can lower $\mathrm{NH}_{3}$ emission from manure. Several studies reported significant reductions (70-90\%) in $\mathrm{NH}_{3}$ emissions when manure was directly acidified with strong acids to $\mathrm{pH}$ of 5.5 to 6.0 from $\mathrm{pH}$ of 7.0 to 7.5 (Hristov et al., 2011; Fangueiro et al., 2015; Kavanagh et al., 2019). However, achieving the manure $\mathrm{pH}$ of 5.5 to 6.0 by feeding a reduced DCAD diet would not be possible for fear of health issues, i.e., this requires considerable reduction of urine $\mathrm{pH}$, causing uncompensated metabolic acidosis (Goff, 2014). Therefore, our intent was not to reduce $\mathrm{NH}_{3}$ emissions as much as with direct manure acidification (i.e., $70-90 \%$ ) but to reduce it by about $20 \%$ or even more (Lee et al., 2020) by feeding a diet with appropriately reduced DCAD. The ratio of 2:1 for feces to urine used to reconstitute manure in the in vitro incubation study is similar to the mean ratio of modern highproducing cows (Weiss et al., 2009; Lee et al., 2012, 2020). Reducing urine $\mathrm{pH}$ from 8.5 to $7.5,6.5$, and 5.5 successfully reduced manure $\mathrm{pH}$ from 7.7 to $7.5,7.1$, and 6.9 , respectively, and reducing urine $\mathrm{pH}$ to 7.5 was even sufficient to depress $\mathrm{NH}_{3}$ emissions from manure by $20 \%$ under this manure incubating condition, indicating that reducing DCAD has potential as a strategy to lower $\mathrm{NH}_{3}$ emissions from manure.

\section{Animal Study}

The effect of DCAD on DMI and lactation performance has been researched. Hu and Murphy (2004),

Table 6. The effect of varying DCAD on production measures of lactating cows in Experiment 2

\begin{tabular}{|c|c|c|c|c|c|c|}
\hline \multirow[b]{2}{*}{ Item } & \multicolumn{3}{|c|}{ DCAD $^{1}$} & \multirow[b]{2}{*}{ SEM } & \multicolumn{2}{|c|}{$P$-value ${ }^{2}$} \\
\hline & HDCAD & MDCAD & LDCAD & & $\mathrm{L}$ & $\mathrm{Q}$ \\
\hline BW change, $\mathrm{kg} / \mathrm{d}$ & 0.23 & 0.28 & 0.23 & 0.104 & 0.99 & 0.73 \\
\hline DMI, $\mathrm{kg} / \mathrm{d}$ & 23.3 & 23.1 & 22.4 & 0.65 & 0.24 & 0.71 \\
\hline Milk yield, $\mathrm{kg} / \mathrm{d}$ & 39.8 & 40.5 & 37.8 & 1.22 & 0.16 & 0.21 \\
\hline $\mathrm{ECM},{ }^{3} \mathrm{~kg} / \mathrm{d}$ & 35.1 & 33.7 & 32.7 & 1.07 & 0.10 & 0.88 \\
\hline ECM/DMI, $\mathrm{kg} / \mathrm{kg}$ & 1.47 & 1.50 & 1.47 & 0.057 & 0.98 & 0.55 \\
\hline Fat, $\%$ & 2.52 & 2.34 & 2.35 & 0.180 & 0.41 & 0.58 \\
\hline Fat, $\mathrm{kg} / \mathrm{d}$ & 1.00 & 0.90 & 0.86 & 0.054 & 0.08 & 0.66 \\
\hline True protein, \% & 3.00 & 3.05 & 3.14 & 0.040 & 0.03 & 0.70 \\
\hline True protein, $\mathrm{kg} / \mathrm{d}$ & 1.18 & 1.22 & 1.16 & 0.033 & 0.70 & 0.21 \\
\hline Lactose, \% & 4.83 & 4.84 & 4.81 & 0.028 & 0.54 & 0.58 \\
\hline Lactose, $\mathrm{kg} / \mathrm{d}$ & 1.93 & 1.96 & 1.79 & 0.070 & 0.15 & 0.20 \\
\hline
\end{tabular}


Iwaniuk and Erdman (2015), and Peters (2020) agree that DMI increases with increasing DCAD [range from -191 to 636 ( $\mathrm{S}$ was not included for the DCAD calculation); -68 to $+811 ; 100$ to $500 \mathrm{mEq} / \mathrm{kg}$ of DM, respectively]. Poor palatability of anionic salts (Oetzel et al., 1988; Oetzel and Barmore, 1993) and metabolic acidosis (Vagnoni and Oetzel, 1998; Zimpel et al., 2018; Santos et al., 2019) are reasons often used to explain decreases in DMI by low DCAD. However, DMI did not decrease as DCAD decreased from 193 to $1 \mathrm{mEq} / \mathrm{kg}$ DM in the current study. There might be a difference in DMI responses among anionic sources used to decrease DCAD. Caixeta et al. (2020) examined 2 commercially available anionic DCAD products (chloride-based) in prepartum cows and found a numerical difference in DMI $(12.2$ vs. $11.0 \mathrm{~kg} / \mathrm{d}, P=0.17)$. The DCAD source with numerically greater DMI in that study was the source used in the current study. Acid-base status altered by DCAD can also affect DMI (Vagnoni and Oetzel, 1998; Zimpel et al., 2018; Santos et al., 2019). Differences in urine $\mathrm{pH}$ indicate cows on LDCAD were in a different acid-base state compared with HDCAD, but the state may have been a compensated metabolic acidosis with minimal change of blood $\mathrm{pH}$. A lack of differences in DMI may also explain the similar milk yield observed in all treatments. Although not statistically different, however, numerical decreases in DMI from 23.3 to $22.4 \mathrm{~kg} / \mathrm{d}$ and milk yield from 39.8 to 37.8

Table 7. Effect of DCAD on milk fatty acid profile as percentages of total fatty acids in Experiment 2

\begin{tabular}{|c|c|c|c|c|c|c|}
\hline \multirow[b]{2}{*}{ Item } & \multicolumn{3}{|c|}{$\mathrm{DCAD}^{1}$} & \multirow[b]{2}{*}{ SEM } & \multicolumn{2}{|c|}{$P$-value ${ }^{2}$} \\
\hline & HDCAD & MDCAD & LDCAD & & $\mathrm{L}$ & Q \\
\hline $4: 0$ & 1.87 & 1.98 & 1.86 & 0.187 & 0.99 & 0.58 \\
\hline $6: 0$ & 1.30 & 1.29 & 1.27 & 0.096 & 0.76 & 0.97 \\
\hline $8: 0$ & 0.60 & 0.57 & 0.57 & 0.042 & 0.60 & 0.68 \\
\hline 10:0 & 1.37 & 1.23 & 1.29 & 0.091 & 0.40 & 0.27 \\
\hline $12: 0$ & 1.93 & 1.73 & 1.82 & 0.086 & 0.33 & 0.14 \\
\hline iso $13: 0$ & 0.02 & 0.03 & 0.03 & 0.001 & 0.20 & 0.40 \\
\hline ante 13:0 & 0.06 & 0.07 & 0.06 & 0.007 & 0.81 & 0.62 \\
\hline $13: 0$ & 0.07 & 0.07 & 0.08 & 0.008 & 0.55 & 0.21 \\
\hline iso $14: 0$ & 0.05 & 0.05 & 0.05 & 0.004 & 0.63 & 0.34 \\
\hline $14: 0$ & 8.61 & 7.87 & 8.03 & 0.270 & 0.13 & 0.17 \\
\hline iso $15: 0$ & 0.14 & 0.14 & 0.15 & 0.007 & 0.46 & 0.60 \\
\hline $15: 0$ & 0.36 & 0.38 & 0.40 & 0.016 & 0.14 & 0.96 \\
\hline cis-9 14:1 & 1.50 & 1.60 & 1.42 & 0.163 & 0.49 & 0.19 \\
\hline $15: 0$ & 0.88 & 0.83 & 0.88 & 0.062 & 0.71 & 0.41 \\
\hline iso $16: 0$ & 0.15 & 0.15 & 0.13 & 0.014 & 0.33 & 0.70 \\
\hline $16: 0$ & 26.4 & 25.0 & 24.8 & 0.73 & 0.13 & 0.50 \\
\hline iso $17: 0$ & 0.45 & 0.46 & 0.47 & 0.014 & 0.11 & 0.87 \\
\hline cis-9 16:1, cis-11 16:1, ante 17:0 & 2.69 & 2.88 & 2.69 & 0.240 & 0.86 & 0.44 \\
\hline $17: 0$ & 0.54 & 0.51 & 0.55 & 0.019 & 0.63 & 0.17 \\
\hline 18:0 & 8.66 & 9.03 & 8.64 & 0.515 & 0.97 & 0.44 \\
\hline trans-6,8 18:1 & 0.93 & 1.00 & 1.02 & 0.055 & 0.21 & 0.76 \\
\hline trans-9 18:1 & 0.69 & 0.83 & 0.74 & 0.062 & 0.55 & 0.14 \\
\hline trans-10 18:1 & 6.67 & 6.26 & 7.85 & 0.676 & 0.23 & 0.24 \\
\hline trans-11 18:1 & 1.27 & 1.13 & 1.07 & 0.106 & 0.13 & 0.67 \\
\hline trans-12 18:1 & 0.90 & 0.87 & 0.96 & 0.021 & 0.01 & 0.01 \\
\hline cis-9 18:1 & 23.6 & 25.7 & 24.2 & 0.62 & 0.47 & 0.03 \\
\hline cis-11 18:1 & 1.15 & 1.13 & 1.18 & 0.088 & 0.79 & 0.72 \\
\hline $18: 2 \mathrm{n}-6$ & 3.12 & 3.10 & 3.46 & 0.107 & 0.04 & 0.16 \\
\hline cis-9,trans-11 18:2 & 0.82 & 0.90 & 0.80 & 0.044 & 0.65 & 0.06 \\
\hline trans-10,cis-12 18:2 & 0.030 & 0.029 & 0.045 & 0.004 & $<0.01$ & 0.07 \\
\hline $18: 3 n-3$ & 0.46 & 0.48 & 0.50 & 0.015 & 0.07 & 0.97 \\
\hline $20: 0$ & 0.09 & 0.09 & 0.09 & 0.009 & 0.93 & 0.74 \\
\hline Unknown & 2.59 & 2.65 & 2.74 & 0.203 & 0.59 & 0.94 \\
\hline$<16 \mathrm{C}$ & 18.8 & 17.8 & 17.9 & 0.66 & 0.30 & 0.44 \\
\hline$\Sigma 16 \mathrm{C}$ & 29.2 & 28.0 & 27.6 & 0.85 & 0.20 & 0.67 \\
\hline$>16 \mathrm{C}$ & 49.4 & 51.5 & 51.7 & 1.01 & 0.11 & 0.40 \\
\hline Total SFA & 53.5 & 51.4 & 51.2 & 1.06 & 0.12 & 0.47 \\
\hline Total MUFA & 39.4 & 41.3 & 41.2 & 0.85 & 0.13 & 0.30 \\
\hline Total PUFA & 4.53 & 4.60 & 4.91 & 0.132 & 0.04 & 0.43 \\
\hline $\mathrm{OBCFA}^{3}$ & 2.98 & 2.95 & 3.11 & 0.085 & 0.30 & 0.36 \\
\hline
\end{tabular}

${ }^{1} \mathrm{HDCAD}=193 \mathrm{mEq} / \mathrm{kg}$ of DM; MDCAD $=101 \mathrm{mEq} / \mathrm{kg}$ of DM; LDCAD $=1 \mathrm{mEq} / \mathrm{kg}$ of DM.

${ }^{2} \mathrm{~L}=$ linear, $\mathrm{Q}=$ quadratic effect of dietary DCAD.

${ }^{3}$ Odd- and branched-chain fatty acids. 
A

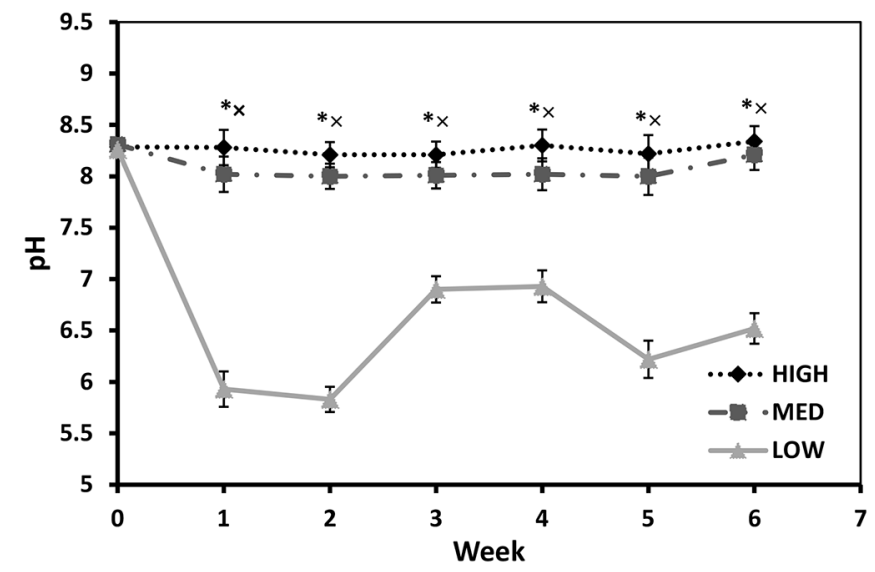

B

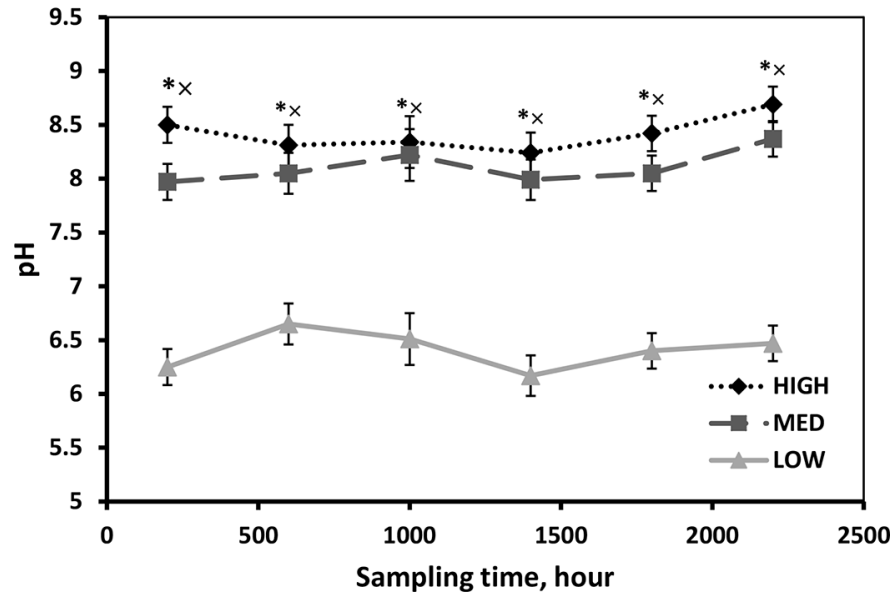

Figure 2. Effect of DCAD on weekly urine $\mathrm{pH}(\mathrm{A})$ or urine $\mathrm{pH}$ within a 24-h cycle (B) in the animal study. High = DCAD of 193 $\mathrm{mEq} / \mathrm{kg}$ of DM; Med $=$ DCAD of $101 \mathrm{mEq} / \mathrm{kg}$ of DM; Low $=$ DCAD of $1 \mathrm{mEq} / \mathrm{kg}$ of DM. Error bars indicate SE of the least squares mean. (A) Linear and quadratic effect $P<0.01$, week effect $P<0.01$, interaction of DCAD by week $P<0.01$; (B) linear effect $P<0.01$ and quadratic effect $P=0.02$, time effect $P<0.01$, interaction of DCAD by time, $P=0.10 .{ }^{*}$ indicates linear effect $(P<0.01), \times$ indicates quadratic effect $(P<0.05)$.

$\mathrm{kg} / \mathrm{d}$ as DCAD decreased are in line with responses to DCAD estimated by Iwaniuk and Erdman (2015). This may indicate that they might have been significant with larger numbers of cows. Altering DCAD for lactating cows usually did not affect milk protein content or yield in the meta-analyses by Iwaniuk and Erdman (2015) and Peters (2020), but a quadratic increase in milk protein yield was also observed in the meta-analysis by $\mathrm{Hu}$ and Murphy (2004). We observed a linear increase in milk protein content but no difference in milk protein yield as DCAD decreased. The change in milk protein content probably occurred due to dilution because of numerically lower milk production as DCAD decreased.

Energy-corrected milk tended to decrease with decreasing DCAD likely due to a trend for reduced milk fat yield. Based on equations from a meta-analysis by Iwaniuk and Erdman (2015), milk fat content decreases by $0.10 \%$ unit and milk fat yield decreases by $36 \mathrm{~g} / \mathrm{d}$ for every $100 \mathrm{mEq} / \mathrm{kg}$ of DM decrease of DCAD. Therefore, this partly explains decreases in milk fat content and yield by about $0.17 \%$ unit and $140 \mathrm{~g} / \mathrm{d}$ for LDCAD versus HDCAD. A recent study by Matamoros et al. (2020) compared sodium acetate and sodium bicarbonate to determine the major factor that affects milk fat synthesis between supplying a FA precursor (i.e., acetate) and increasing DCAD. In that study, both sodium acetate and sodium bicarbonate increased milk fat yield similarly but with different mechanisms. Increasing DCAD from 176 to $575 \mathrm{mEq} /$ $\mathrm{kg}$ of DM with sodium bicarbonate increased $0.2 \mathrm{~kg} / \mathrm{d}$ of milk fat compared with control and the authors assumed that the increased milk fat occurred because sodium bicarbonate increased DCAD, leading to greater buffering capacity, and may have improved overall diet digestibility. However, total-tract diet digestibility (except for CP) was not altered by different DCAD in the current study (see more discussion later). Milk fat content was quite low for all cows regardless of DCAD (on average $2.4 \%$ ), which is the level to be considered milk fat depression. According to previous studies (Beckman and Weiss, 2005; Lock et al., 2006), the ratio of forage to concentrate in our experimental diets was not likely the major factor for the milk fat depression. Dietary starch concentration was about 2 percentage units greater than formulated, but $26 \%$ starch is still within a typical range for lactating cows (Ferraretto et al., 2013). However, upon further analysis of the diets, linoleic acid concentration (C18:2n-6; LA) in the diets was relatively high, as $33 \%$ of total FA and almost $1.2 \%$ of total DM. This LA concentration is similar to a diet used in the study by Copelin et al. (2021) that observed milk fat depression by feeding a diet with $30 \%$ starch and supplemented with LA. In addition, trans-10 C18:1 concentration in milk fat was substantial $(6.93 \%$ on average) regardless of treatments in the current study, and this percentage is usually seen during milk fat depression (Matamoros et al., 2020). Baldin et al. (2018) reported that starch and LA are positively correlated in corn silage, suggesting that high starch corn silage can contain up to $1.6 \%$ LA of dietary DM. Corn silage was the base of all experimental diets (53\% DM basis) and had $36 \%$ starch (DM basis), which is the upper end of the normal 25 to $35 \%$ range (NRC, 2001). In the current study, the corn silage may have contributed $0.87 \%$ of DM as LA and may have, at least in part, contributed to milk fat depression. Furthermore, the fat supplement used in the diets unexpectedly included $38 \%$ LA and $20 \%$ SFA and this fat source could be another factor for high PUFA supply and milk fat depression. 
It is worth noting that DMI and production responses to reduced DCAD may depend on the composition of a basal diet. Apper-Bossard et al. (2006) examined 30 and $37 \%$ starch levels (i.e., low concentrate with high forage and high concentrate with low forage, respectively) with different DCAD levels of about 11, 163, and $317 \mathrm{mEq} / \mathrm{kg}$ of DM. In that study, DMI and milk fat yield had interactions of starch by DCAD where no responses to DCAD were observed with the $30 \%$ starch diet, whereas DMI and milk fat yield increased as DCAD increased under the $37 \%$ starch diet.

Changes in milk FA profile by DCAD have been observed previously. Apper-Bossard et al. (2006) increased DCAD from 4 to $327 \mathrm{mEq} / \mathrm{kg}$ of DM, reporting increases in de novo synthesized FA in milk. Potentially this could be a function of improved rumen buffering (Zebeli et al., 2011; Guo et al., 2013), improving NDF digestibility, and consequently increasing acetate production (Kaufmann et al., 1980), the main substrate of de novo FA synthesis (Urrutia and Harvatine, 2017; Matamoros et al., 2020). We did not observe changes in de novo milk FA as DCAD decreased, likely because of no difference in NDF digestibility (to be discussed later) and milk fat depression regardless of dietary treatments. Apper-Bossard et al. (2006) did not see changes in milk PUFA, but Roche et al. (2005) ob- served a linear decrease of C18:2 and a quadratic effect of $\mathrm{C} 18: 3$ as DCAD increased. Contrary to the latter study, we observed an increase in total PUFA, C18:2, and C18:3, and CLA trans-10,cis-12 C18:2 in milk fat as DCAD decreased. This may indicate that rumen biohydrogenation capacity may have been decreased to some extent with decreased DCAD, causing greater PUFA in milk (Kalscheur et al., 1997; Piperova et al., 2002). However, the decrease in buffering capacity by decreased DCAD was not severe enough to affect digestibility.

Apparent nutrient digestibility was another parameter that can be impaired when a diet with reduced DCAD is fed to cows. A meta-analysis showed that DM and NDF digestibility increased linearly as DCAD increased from 13 to $436 \mathrm{mEq} / \mathrm{kg}$ of DM (Iwaniuk and Erdman, 2015). However, we found no effect on DM, $\mathrm{OM}$, and NDF digestibility and our results agree with Apper-Bossard et al. (2010; DCAD of 11 to $327 \mathrm{mEq} /$ $\mathrm{kg}$ of DM) and Rajeerad et al. (2021; DCAD of -115 to $95 \mathrm{mEq} / \mathrm{kg}$ of DM). Perhaps, DCAD effects on diet digestibility is also dependent upon a basal diet composition as discussed for DMI and production earlier. However, Apper-Bossard et al. (2010) examined an interaction of starch levels and DCAD levels on digestibility and no interaction was observed. Therefore, the

Table 8. Effect of DCAD on fecal, urine, manure characteristics, and $\mathrm{NH}_{3}$ emissions from manure

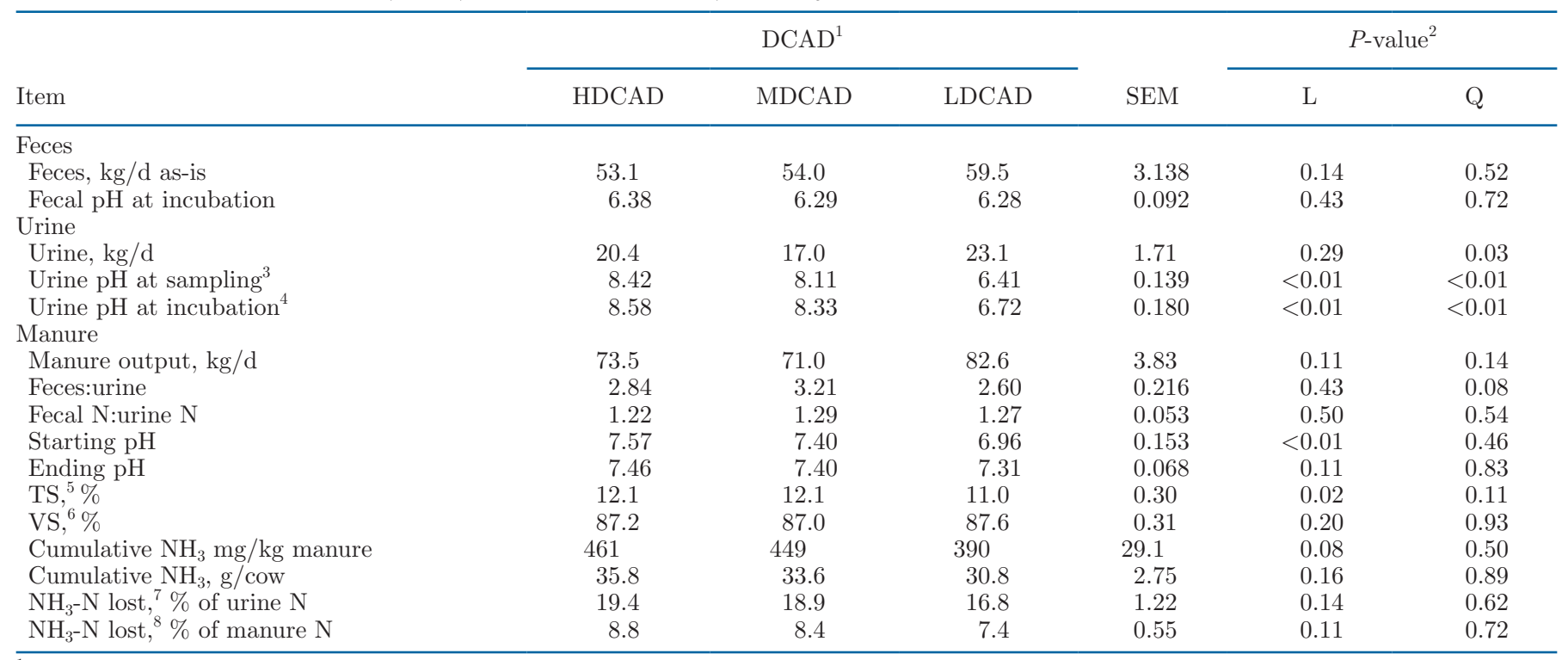

${ }^{1} \mathrm{HDCAD}=193 \mathrm{mEq} / \mathrm{kg}$ DM; MDCAD $=101 \mathrm{mEq} / \mathrm{kg}$ DM; LDCAD $=1 \mathrm{mEq} / \mathrm{kg}$ DM.

${ }^{2} \mathrm{~L}=$ linear, $\mathrm{Q}=$ quadratic effect of dietary DCAD.

${ }^{3}$ At time of spot sampling.

${ }^{4}$ At time of incubation after freezing and thawing.

${ }^{5}$ Total solids (i.e., DM).

${ }^{6}$ Volatile solids (i.e., OM\% of DM).

${ }^{7}$ Cumulative $\mathrm{NH}_{3}-\mathrm{N}(\mathrm{g} /$ cow $) \div$ urine $\mathrm{N}(\mathrm{g} /$ cow $) \times 100$.

${ }^{8}$ Cumulative $\mathrm{NH}_{3}-\mathrm{N}(\mathrm{g} /$ cow $) \div$ manure $\mathrm{N}(\mathrm{g} /$ cow $) \times 100$. 
authors in that study concluded that DCAD effect on diet digestibility is minor. In contrary, Martins et al. (2016) examined DCAD from 290 to $-71 \mathrm{mEq} / \mathrm{kg}$ of DM and observed a linear decrease in NDF digestibility (71 to $65 \%$ ) as DCAD decreased where DCAD was reduced by removing sodium bicarbonate and increasing ammonium sulfate. The decrease in NDF digestibility in that study might have been sulfate effect rather than DCAD effect. Decreased digestibility from feeding a diet containing high sulfate (from distillers grains) was observed (Morris et al., 2018b) and high sulfate supply may negatively affect rumen microbial growth and fermentation (van Zijderveld et al., 2010). We observed a tendency for CP digestibility to decrease with decreasing DCAD. This contradicts studies examining the effect of DCAD on CP digestibility (Martins et al., 2016; Rajeerad et al., 2021). The decrease in dietary CP digestibility as DCAD decreased in the current
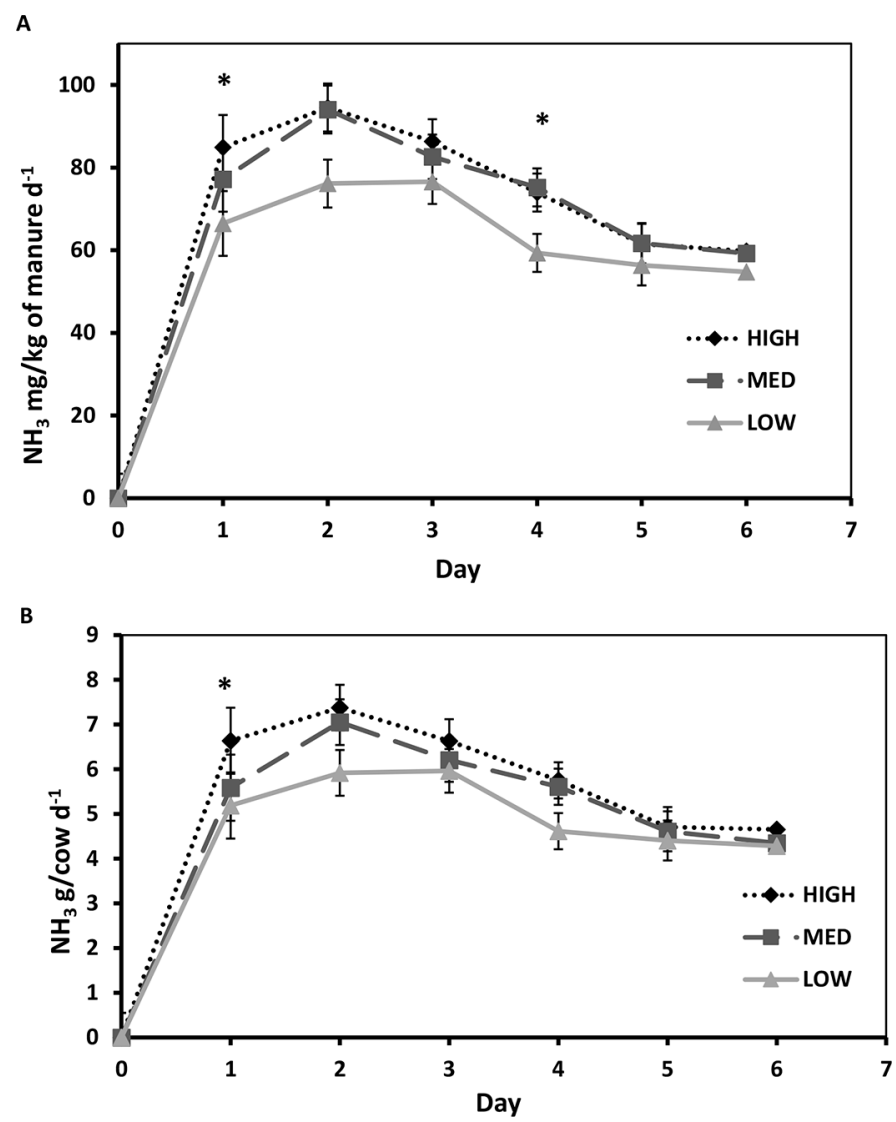

Figure 3. Effect of DCAD on $\mathrm{NH}_{3}$ emissions from manure over the course of a 6-d incubation on a basis of kilograms of manure (A) or on a basis of cow (B). High $=$ DCAD of $193 \mathrm{mEq} / \mathrm{kg}$ of DM; Med $=\mathrm{DCAD}$ of $101 \mathrm{mEq} / \mathrm{kg}$ of DM; Low $=\mathrm{DCAD}$ of $1 \mathrm{mEq} / \mathrm{kg}$ of DM. Error bars indicate SE of the least squared mean. (A) Linear effect $P$ $=0.07$, day effect $P<0.01$, interaction of DCAD by day $P=0.17$; (B) linear effect $P=0.16$, day effect $P<0.01$, interaction of DCAD by day $P=0.18$. ${ }^{*}$ indicates linear effect $(P<0.05)$. study was probably due to numerical decreases in $\mathrm{CP}$ intake as DCAD decreased, resulting in greater dilution of undigested dietary $\mathrm{CP}$ with metabolic fecal $\mathrm{N}$ (Olmos Colmenero and Broderick, 2006) or perhaps different sources of NPN (i.e., ammonium chloride vs. urea) resulted in the change of $\mathrm{CP}$ digestibility.

Few studies are available on effects of DCAD on dietary $\mathrm{N}$ utilization and excretion. In a beef study comparing $-160 \mathrm{mEq} / \mathrm{kg}$ of $\mathrm{DM}$ and $200 \mathrm{mEq} / \mathrm{kg}$ of DM of DCAD, fecal and urinary N excretion $(\mathrm{g} / \mathrm{d})$ were unaffected by DCAD (Luebbe et al., 2011). Delaquis and Block (1995) also reported that fecal and urine $\mathrm{N}$ were not altered with DCAD from 140 to $373 \mathrm{mEq} /$ $\mathrm{kg}$ of DM. Our results of fecal and urine $\mathrm{N}$ excretion agree with the results in those studies. A decrease in $\mathrm{N}$ balance with decreasing DCAD in the current study was observed. Delaquis and Block (1995) observed that mid-lactation cows tended to retain less $\mathrm{N}$ as DCAD decreased from $373 \mathrm{mEq} / \mathrm{kg}$ of DM of DCAD to 140 $\mathrm{mEq} / \mathrm{kg}$ of $\mathrm{DM}$, but when $\mathrm{N}$ balance was expressed as percent of $\mathrm{N}$ intake, the DCAD effect was not apparent. Luebbe et al. (2011) also did not observe differences in $\mathrm{N}$ retention in beef steers. Therefore, the decrease in $\mathrm{N}$ balance as DCAD decreased could be a result from numerical differences in $\mathrm{N}$ intake without differences in $\mathrm{N}$ excretion in urine and feces and $\mathrm{N}$ secretion in milk.

Urine $\mathrm{pH}$ is well documented to decrease as DCAD decreases (Hu and Murphy, 2004; Charbonneau et al., 2006; Lean et al., 2019) and has been used to monitor DCAD efficacy in prepartum cows (Vagnoni and Oetzel, 1998; Goff, 2014). Ganjkhanlou et al. (2010) reduced urine $\mathrm{pH}$ from 7.99 at $\mathrm{DCAD}$ of $130 \mathrm{mEq} /$ $\mathrm{kg}$ of DM to 6.81 with DCAD of $0 \mathrm{mEq} / \mathrm{kg}$ of DM. Similarly, Apper-Bossard et al. (2010) observed a urine $\mathrm{pH}$ of 6.59 with DCAD of $11 \mathrm{mEq} / \mathrm{kg}$ of $\mathrm{DM}$ versus urine $\mathrm{pH} 8.32$ with DCAD of $169 \mathrm{mEq} / \mathrm{kg}$ DM. Urine $\mathrm{pH}$ of 6.4 for LDCAD in the current study agrees with those previous studies above. However, an interaction of DCAD by wk for urine $\mathrm{pH}$ (Figure 2) occurred because urine $\mathrm{pH}$ for LDCAD changed through the experiment. Urine $\mathrm{pH}$ for LDCAD considerably decreased in wk 1 and 2 (5.89), increased in wk 3 and 4 (6.91), and then decreased in wk 5 and 6 (6.37). The interaction is difficult to explain, but this was not likely a result of adaptation to the diet because the urine $\mathrm{pH}$ went down in wk 5 and 6 after the $\mathrm{pH}$ increase in wk 3 and 4 . This could be a result from batch-to-batch variability of the concentrate for LDCAD that was prepared at the feed mill every 2 or 3 wk. We observed a quadratic increase in urine output as DCAD decreased. Typically, an increase in urine volume is associated with increasing DCAD (Delaquis and Block, 1995; Nennich et al., 2006; $\mathrm{Hu}$ et al., 2007) because increasing $\mathrm{Na}$ and $\mathrm{K}$ in the diet can increase water intake and urine output (Fisher 
et al., 1994; Eriksson and Rustas, 2014). Urination is the homeostatic regulator for $\mathrm{Cl}^{-}$, not only for $\mathrm{Na}^{+}$and $\mathrm{K}^{+}$(Miller, 1975; Maltz and Silanikove, 1996). Therefore, decreasing DCAD with additional Cl supply can also increase urine output (Miller, 1975; Zimpel et al., 2018). Apper-Bossard et al. (2010) decreased DCAD from a base diet with $169 \mathrm{mEq} / \mathrm{kg}$ of $\mathrm{DM}$ to $16 \mathrm{mEq} / \mathrm{kg}$ of DM using $\mathrm{Cl}$. They also increased the DCAD from 169 to $327 \mathrm{mEq} / \mathrm{kg}$ of $\mathrm{DM}$ using $\mathrm{Na}$; the decreased and increased DCAD diets had greater urine output than the intermediate base diet.

Studies on the effects of DCAD on feces and manure output are limited. One study observed a linear decrease in fecal output as DCAD increased from -71 to $290 \mathrm{mEq} / \mathrm{kg}$ of DM (Martins et al., 2016), likely due to increased NDF digestibility. No difference in fecal output in the current study was probably because of similar DMI and NDF digestibility among treatments. Despite the changes in urine outputs, manure outputs were not affected by DCAD. In the present study, the fecal-to-urine ratio averaged 2.9:1, which is at the high end of the range (Weiss et al., 2009) and much greater than the ratio $(<2: 1)$ used previously to reconstitute manure (Lee et al., 2012, 2020). The fixed rate of creatinine excretion $(29 \mathrm{mg} / \mathrm{kg}$ of BW per day) when urine outputs were estimated might be a factor underestimating urine volume. However, when urine outputs were estimated using an equation developed with dietary K content by Weiss et al. (2009; urine output = $19.2 \times 1.28 \% \mathrm{~K}-2.91$ ), it resulted in on average 21.7 $\mathrm{kg} / \mathrm{d}$ of urine for cows in the current study, which is close to the outputs in Table 8. This suggests that urine output may have been small and not underestimated in the current study, and the low urine outputs may have occurred due to low $\mathrm{K}$ content in the diets (actual vs. formulated, 1.28 vs. 1.6\%). This high ratio of feces to urine in the current study may be the reason that the effectiveness of reduced DCAD on $\mathrm{NH}_{3}$ emissions from manure was low (see the details later).

Fecal pH did not differ, as expected based on previous studies (Luebbe et al., 2011; Lee et al., 2020), but manure $\mathrm{pH}$ was reduced below 7.0 for LDCAD. Reducing manure $\mathrm{pH}$ below 7.0 is likely low enough to reduce $\mathrm{NH}_{3}$ volatilization to some extent (Muck, 1982; Sokolov et al., 2019), as observed in the in vitro incubation study. However, manure $\mathrm{NH}_{3}$ emissions per cow were only numerically decreased by $15 \%$ for LDCAD compared with HDCAD. Similar results were observed when $\mathrm{NH}_{3}-\mathrm{N}$ losses were expressed as percent of urine $\mathrm{N}$ (linear $P=0.14$ ) or manure $\mathrm{N}$ (linear $P=0.11$ ). Several factors may have prevented a significant decrease in $\mathrm{NH}_{3}$ emissions. First, the ratio of feces to urine in the current study was greater than the ratios often observed in modern dairy cows, as already discussed. An increase in proportion of feces in manure increases the buffering capacity of the manure and attenuates changes in manure $\mathrm{pH}$ by urine with low $\mathrm{pH}$ (Kavanagh et al., 2019). Furthermore, ratios of feces to urine varied from 1.3:1 to $4.2: 1$ and total manure outputs from 54.6 to $102 \mathrm{~kg} / \mathrm{d}$ among cows in the current study, indicating large cowto-cow variation. This may reflect that the number of observations had insufficient statistical power to detect significance of $\mathrm{NH}_{3}$ emission for LDCAD. Second, urine $\mathrm{pH}$ was increased by $0.3 \mathrm{pH}$ unit for LDCAD during freezing and thawing of urine after collection, reducing the potency of the urine in reducing manure $\mathrm{pH}$ and then $\mathrm{NH}_{3}$ emission. Increases of almost $0.5 \mathrm{pH}$ units is documented in human urine $\mathrm{pH}$ after freezing and thawing (Cook et al., 2007) likely due to carbon dioxide loss and carbonic acid dissociation (Rist et al., 2013). Therefore, a $15 \%$ reduction in manure $\mathrm{NH}_{3}$ emission for LDCAD versus HDCAD could have been greater and statistically significant with a lower ratio of feces to urine $(<2: 1)$ and greater number of observations, and without urine storage before manure incubation. However, any strategies that negatively affect production of cows would not be adopted even though they are effective in lowering $\mathrm{NH}_{3}$ emission from manure. The current study observed numerical decrease in milk yield and a tendency for decreased milk fat yield suggesting that the DCAD of $1 \mathrm{mEq} / \mathrm{kg}$ of DM for LDCAD was probably too low and DCAD levels greater than that would be necessary in the follow-up studies (e.g., 50 $\mathrm{mEq} / \mathrm{kg}$ of DM).

\section{CONCLUSIONS}

The in vitro incubation study with direct decreases in urine $\mathrm{pH}$ with acids indicated that lowering urine $\mathrm{pH}$ from 8.5 to 7.5 and 6.5 could reduce $\mathrm{NH}_{3}$ emissions about 20 and $30 \%$, respectively, when fecal-to-urine ratios were close to $2: 1$. In the animal study, although a diet with DCAD of $1 \mathrm{mEq} / \mathrm{kg}$ of DM decreased urine $\mathrm{pH}$ and manure $\mathrm{pH}$ compared with a diet with DCAD of $193 \mathrm{mEq} / \mathrm{kg}$ of $\mathrm{DM}$, the decrease in $\mathrm{NH}_{3}$ emissions (15\%) was less than that observed in the in vitro incubation study, which likely occurred due to the high ratio of feces to urine $(2.9: 1)$. Furthermore, although DMI was not affected by DCAD levels, a tendency for decreased milk fat yield and ECM indicated that reduction of DCAD to $1 \mathrm{mEq} / \mathrm{kg}$ of DM was likely too low for lactating cows. More studies are needed to examine relatively less reduced DCAD levels (e.g., $50 \mathrm{mEq} / \mathrm{kg}$ of $\mathrm{DM}$ ) that can lower urine $\mathrm{pH}$ enough to reduce $\mathrm{NH}_{3}$ emissions without negatively affecting performance of lactation cows. 


\section{ACKNOWLEDGMENTS}

This project was partly supported by Origination LLC and the Department of Animal Sciences, The Ohio State University. The authors thank all staff at Krauss Dairy Research Center (The Ohio State University, Wooster, $\mathrm{OH}$ ) for animal husbandry assistance. Gratitude is also extended to Phyllis Dieter and Donna Wyatt (The Ohio State University, Wooster, $\mathrm{OH}$ ) for their assistance in performing laboratory analysis. Author Fei Sun is employed by the external funding entity (Origination LLC). The other authors have not stated any conflicts of interest.

\section{REFERENCES}

Anderson, N., R. Strader, and C. Davidson. 2003. Airborne reduced nitrogen: ammonia emissions from agriculture and other sources. Environ. Int. 29:277-286. https://doi.org/10.1016/S0160 -4120(02)00186-1.

AOAC International. 2000. Official Methods of Analysis. 17th ed. Vol. 1 and 2. AOAC International.

Apper-Bossard, E., P. Faverdin, F. Meschy, and J. L. Peyraud. 2010. Effects of dietary cation-anion difference on ruminal metabolism and blood acid-base regulation in dairy cows receiving 2 contrasting levels of concentrate in diets. J. Dairy Sci. 93:4196-4210. https: //doi.org/10.3168/jds.2009-2975.

Apper-Bossard, E., J. L. Peyraud, P. Faverdin, and F. Meschy. 2006. Changing dietary cation-anion difference for dairy cows fed with two contrasting levels of concentrate in diets. J. Dairy Sci. 89:749760. https://doi.org/10.3168/jds.S0022-0302(06)72136-1.

Baldin, M., Y. Ying, Y. Fan, G. Roth, D. P. Casper, and K. J. Harvatine. 2018. Characterization of linoleic acid (C18:2) concentration in commercial corn silage and grain hybrids. J. Dairy Sci. 101:222-232. https://doi.org/10.3168/jds.2017-12972.

Beckman, J. L., and W. P. Weiss. 2005. Nutrient digestibility of diets with different fiber to starch ratios when fed to lactating dairy cows. J. Dairy Sci. 88:1015-1023. https://doi.org/10.3168/jds .S0022-0302(05)72769-7.

Bougouin, A., A. Leytem, J. Dijkstra, R. S. Dungan, and E. Kebreab. 2016. Nutritional and Environmental effects on ammonia emissions from dairy cattle housing: A meta-analysis. J. Environ. Qual. 45:1123-1132. https://doi.org/10.2134/jeq2015.07.0389.

Caixeta, L. S., W. J. Weber, D. M. Johnson, J. Faser, B. M. Visser, and B. A. Crooker. 2020. Effects of anionic supplement source in prepartum negative dietary cation-anion difference diets on serum calcium, feed intake, and lactational performance of multiparous dairy cows. J. Dairy Sci. 103:4302-4314. https://doi.org/10.3168/ jds.2019-16991.

Chadwick, D. R. 2005. Emissions of ammonia, nitrous oxide, and methane from cattle manure heaps: Effect of compaction and covering. Atmos. Environ. 39:787-799. https://doi.org/10.1016/j .atmosenv.2004.10.012.

Charbonneau, E., D. Pellerin, and G. R. Oetzel. 2006. Impact of lowering dietary cation-anion difference in nonlactating dairy cows: A meta-analysis. J. Dairy Sci. 89:537-548. https://doi.org/10.3168/ jds.S0022-0302(06)72116-6.

Cole, N. A., M. S. Brown, and J. C. MacDonald. 2008. Environmental considerations of feeding bio-fuel co-products. J. Anim. Sci. 86(Suppl. E):157. (Abstr.)

Cook, J. D., K. A. Strauss, Y. H. Caplan, C. P. LoDico, and D. M. Bush. 2007. Urine $\mathrm{pH}$ : The effects of time and temperature after collection. J. Anal. Toxicol. 31:486-496. https://doi.org/10.1093/ jat/31.8.486.

Copelin, J. E., J. L. Firkins, M. T. Socha, and C. Lee. 2021. Effects of diet fermentability and supplementation of 2-hydroxy4-(methylthio)-butanoic acid and isoacids on milk fat depression:
1. Production, milk fatty acid profile, and nutrient digestibility. J. Dairy Sci. 104:1591-1603. https://doi.org/10.3168/jds.2020-18949.

Delaquis, A. M., and E. Block. 1995. Dietary cation-anion difference, acid-base status, mineral metabolism, renal function, and milk production of lactating cows. J. Dairy Sci. 78:2259-2284. https:// doi.org/10.3168/jds.S0022-0302(95)76853-9.

Dennis, R., R. Haeuber, T. Blett, J. Cosby, C. Driscoll, J. Sickles, and J. Johnston. 2007. Sulfur and nitrogen deposition on ecosystems in the United States. Environ. Manage. 12-17.

Eriksson, T., and B. O. Rustas. 2014. Effects on milk urea concentration, urine output, and drinking water intake from incremental doses of potassium bicarbonate fed to mid-lactation dairy cows. J. Dairy Sci. 97:4471-4484. https://doi.org/10.3168/jds.2013-7861.

Fangueiro, D., M. Hjorth, and F. Gioelli. 2015. Acidification of animal slurry - A review. J. Environ. Manage. 149:46-56. https://doi.org/ 10.1016/j.jenvman.2014.10.001.

Ferraretto, L. F., P. M. Crump, and R. D. Shaver. 2013. Effect of cereal grain type and corn grain harvesting and processing methods on intake, digestion, and milk production by dairy cows through a meta-analysis. J. Dairy Sci. 96:533-550. https://doi.org/10.3168/ jds.2012-5932

Fisher, L. J., N. Dinn, R. M. Tait, and J. A. Shelford. 1994. Effect of level of dietary potassium on the absorption and excretion of calcium and magnesium by lactating cows. Can. J. Anim. Sci. 74:503-509. https://doi.org/10.4141/cjas94-071.

Ganjkhanlou, M., A. Nikkhah, and A. Zali. 2010. Effect of dietary cation-anion balance on milk production and blood mineral of Holstein cows during the last two months of pregnancy. Afr. J. Biotechnol. 9:5983-5988.

Goff, J. P. 2014. Calcium and magnesium disorders. Vet. Clin. North Am. Food Anim. Pract. 30:359-381. https://doi.org/10.1016/j .cvfa.2014.04.003.

Guo, Y., X. Xu, Y. Zou, Z. Yang, S. Li, and Z. Cao. 2013. Changes in feed intake, nutrient digestions, plasma metabolites, and oxidative stress parameters in dairy cows with subacute ruminal acidosis and its regulation with pelleted beet pulp. J. Anim. Sci. Biotechnol. 4:31. https://doi.org/10.1186/2049-1891-4-31.

Holm, J., I. Bjorck, A. Drews, and N. G. Asp. 1986. A rapid method for the analysis of starch. Stärke 38:224-226. https://doi.org/10 $.1002 /$ star. 19860380704 .

Hristov, A. N. 2011. Technical note: Contribution of ammonia emitted from livestock at atmospheric fine particulate matter $\left(\mathrm{PM}_{2.5}\right)$ in the United States. J. Dairy Sci. 94:3130-3136. https://doi.org/10 .3168/jds.2010-3681.

Hristov, A. N., M. Hanigan, A. Cole, R. Todd, T. A. McAllister, P. M. Ndegwa, and A. Rotz. 2011. Review: Ammonia emissions from dairy farms and beef feedlots. Can. J. Anim. Sci. 91:1-35.

Hu, W., and M. R. Murphy. 2004. Dietary cation-anion difference effects on performance and acid-base status of lactating dairy cows: A meta-analysis. J. Dairy Sci. 87:2222-2229. https://doi.org/10 .3168/jds.S0022-0302(04)70042-9.

Hu, W., M. R. Murphy, P. D. Constable, and E. Block. 2007. Dietary cation-anion difference and dietary protein effects on performance and acid-base status of dairy cows in early lactation. J. Dairy Sci. 90:3355-3366. https://doi.org/10.3168/jds.2006-514.

Huhtanen, P., K. Kaustell, and S. Jaakkola. 1994. The use of internal markers to predict total digestibility and duodenal flow of nutrient in cattle given six different diets. Anim. Feed Sci. Technol. 48:211-227. https://doi.org/10.1016/0377-8401(94)90173-2.

Iwaniuk, M. E., and R. A. Erdman. 2015. Intake, milk production, ruminal, and feed efficiency responses to dietary cation-anion difference by lactating dairy cows. J. Dairy Sci. 98:8973-8985. https: //doi.org/10.3168/jds.2015-9949.

Jenkins, T. C. 2010. Technical note: Common analytical errors yielding inaccurate results during analysis of fatty acids in feed and digesta samples. J. Dairy Sci. 93:1170-1174. https://doi.org/10 .3168/jds.2009-2509.

Kalscheur, K. F., B. B. Teter, L. S. Piperova, and R. A. Erdman. 1997. Effect of dietary forage concentration and buffer addition on duodenal flow of trans- $\mathrm{C}_{18: 1}$ fatty acids and milk fat production in dairy cows. J. Dairy Sci. 80:2104-2114. 
Kaufmann, W., H. Hagemeister, and G. Dirksen. 1980. Adaptations in dietary composition, level, and frequency of feeding. Pages 587602 in Digestive Physiology and Metabolism in Ruminants. Y. Ruckebusch and P. Thivend, ed. MTP Press Limited.

Kavanagh, I., W. Burchill, M. G. Healy, O. Fenton, D. J. Krol, and G. J. Lanigan. 2019. Mitigation of ammonia and greenhouse gas emissions from stored cattle slurry using acidifiers and chemical amendments. J. Clean. Prod. 237:117822. https://doi.org/10 .1016/j.jclepro.2019.117822.

Kononoff, P. J., A. J. Heinrichs, and H. A. Lehman. 2003. The effect of corn silage particle size on eating behavior, chewing activities, and rumen fermentation in lactating dairy cows. J. Dairy Sci. 86:33433353. https://doi.org/10.3168/jds.S0022-0302(03)73937-X.

Lean, I. J., J. E. P. Santos, E. Block, and H. M. Golder. 2019. Effects of prepartum dietary cation-anion difference intake on production and health of dairy cows: A meta-analysis. J. Dairy Sci. 102:21032133. https://doi.org/10.3168/jds.2018-14769.

Lee, C., A. N. Hristov, C. J. Dell, G. W. Feyereisen, J. Kaye, and D. Beegle. 2012. Effect of dietary protein concentration on ammonia and greenhouse gas emitting potential of dairy manure. J. Dairy Sci. 95:1930-1941. https://doi.org/10.3168/jds.2010-4141.

Lee, C., D. L. Morris, and P. A. Dieter. 2019. Validating and optimizing spot sampling of urine to estimate urine output with creatinine as a marker in dairy cows. J. Dairy Sci. 102:236-245.

Lee, C., D. L. Morris, K. M. Lefever, and P. A. Dieter. 2020. Feeding a diet with corn distillers' grain with solubles to dairy cows alters manure characteristics and ammonia and hydrogen sulfide emissions from manure. J. Dairy Sci. 103:2363-2372. https://doi.org/ $10.3168 /$ jds.2019-17524.

Lock, A. L., T. R. Overton, K. J. Harvatine, J. Giesy, and D. E. Bauman. 2006. Milk fat depression: Impact of dietary components and their interaction during rumen fermentation. Pages 75-85 in Proc. Cornell Nutr. Conf. Cornell University.

Luebbe, M. K., G. E. Erickson, T. J. Klopfenstein, M. A. Greenquist, and J. R. Benton. 2011. Effect of dietary cation-anion difference on urinary $\mathrm{pH}$, feedlot performance, nitrogen mass balance, and manure pH in open feedlot pens. J. Anim. Sci. 89:489-500. https:/ /doi.org/10.2527/jas.2009-2458.

Maltz, E., and N. Silanikove. 1996. Kidney function and nitrogen balance of high yielding dairy cows at the onset of lactation. J. Dairy Sci. 79:1621-1626. https://doi.org/10.3168/jds.S0022 $-0302(96) 76525-6$.

Martins, C. M. M. R., M. A. Arcari, K. C. Welter, J. L. Gonçalves, and M. V. Santos. 2016. Effect of dietary cation-anion difference on ruminal metabolism, total apparent digestibility, blood, and renal acid-base regulation in lactating dairy cows. Animal 10:64-74. https://doi.org/10.1017/S1751731115001548.

Matamoros, C., R. N. Klopp, L. E. Moraes, and K. J. Harvatine. 2020. Meta-analysis of the relationship between milk trans-10 C18:1, milk fatty acids $<16 \mathrm{C}$, and milk fat production. J. Dairy Sci. 103:10195-10206. https://doi.org/10.3168/jds.2019-18129.

McIlroy, J. P., K. L. McGeough, R. J. Laughlin, and R. Carolan. 2019. Abatement of ammonia emissions from dairy cow house concrete floor surfaces through additive application. Biosyst. Eng. 188:320330. https://doi.org/10.1016/j.biosystemseng.2019.10.016.

Miller, W. J. 1975. New concepts and developments in metabolism and homeostasis of inorganic elements in dairy cattle. A review. J. Dairy Sci. 58:1549-1560. https://doi.org/10.3168/jds.S0022 -0302(75)84751-5.

Morris, D. L., S. H. Kim, P. J. Kononoff, and C. Lee. 2018a. Continuous 11-week feeding of reduced-fat distillers grains with and without monensin reduces lactation performance of dairy cows. J. Dairy Sci. 101:5971-5983. https://doi.org/10.3168/jds.2017-14170.

Morris, D. L., S. H. Kim, and C. Lee. 2018b. Effects of corn feeding reduced-fat distillers grains with or without monensin on nitrogen, phosphorus, and sulfur utilization and excretion in dairy cows. J. Dairy Sci. 101:7106-7116. https://doi.org/10.3168/jds.2018-14528.

Morris, D. L., L. R. Rebelo, P. A. Dieter, and C. Lee. 2018c. Validating intrinsic markers and optimizing spot sampling frequency to estimate fecal outputs. J. Dairy Sci. 101:7980-7989. https://doi .org/10.3168/jds.2018-14717.
Morris, D. L., A. W. Tebbe, W. P. Weiss, and C. Lee. 2019. Short Communication: Effects of drying and analytical methods on nitrogen concentrations of feeds, feces, milk, and urine of dairy cows. J. Dairy Sci. 102:5212-5218. https://doi.org/10.3168/jds.2019-16256.

Muck, R. E. 1982. Urease activity in bovine feces. J. Dairy Sci. 65:2157-2163. https://doi.org/10.3168/jds.S0022-0302(82)82475 -2 .

Ndegwa, P. M., A. N. Hristov, J. Arogo, and R. E. Sheffield. 2008. A review of ammonia emission mitigation techniques for concentrated animal feeding operations. Biosyst. Eng. 100:453-469. https:// doi.org/10.1016/j.biosystemseng.2008.05.010.

Nennich, T. D., J. H. Harrison, L. M. VanWieringen, N. R. St-Pierre, R. L. Kincaid, M. A. Wattiaux, D. L. Davidson, and E. Block. 2006. Prediction and evaluation of urine and urinary nitrogen and mineral excretion from dairy cattle. J. Dairy Sci. 89:353-364. https://doi.org/10.3168/jds.S0022-0302(06)72101-4.

NRC (National Research Council). 2001. Nutrient Requirements of Dairy Cattle. 7th rev. ed. Natl. Acad. Press.

Oetzel, G. R., and J. A. Barmore. 1993. Intake of a concentrate mixture containing various anionic salts fed to pregnant, nonlactating dairy cows. J. Dairy Sci. 76:1617-1623. https://doi.org/10.3168/ jds.S0022-0302(93)77495-0.

Oetzel, G. R., J. D. Olson, C. R. Curtis, and M. J. Fettman. 1988. Ammonium chloride and ammonium sulfate for prevention of parturient paresis in dairy cows. J. Dairy Sci. 71:3302-3309. https:// doi.org/10.3168/jds.S0022-0302(88)79935-X.

Olmos Colmenero, J. J., and G. A. Broderick. 2006. Effect of dietary crude protein concentration on milk production and nitrogen utilization in lactating dairy cows. J. Dairy Sci. 89:1704-1712. https:/ /doi.org/10.3168/jds.S0022-0302(06)72238-X.

Peters, J. P. 2020. Impact of non-fiber carbohydrates and dietary cation-anion difference on milk fat yield in lactating cows: A meta-analysis. MS Thesis. Department of Animal Science, Univ. of Idaho, Moscow.

Piperova, L. S., J. Sampugna, B. B. Teter, K. F. Kalscheur, M. P. Yurawecz, Y. Ku, K. M. Morehouse, and R. A. Erdman. 2002. Duodenal and milk trans octadecenoic acid and conjugated linoleic acid (CLA) isomers indicate that postabsorptive synthesis is the predominant source of cis-9-containing CLA in lactating dairy cows. J. Nutr. 132:1235-1241. https://doi.org/10.1093/jn/ 132.6.1235.

Rajaeerad, A., G. R. Ghorbani, M. Korvash, A. Sadeghi-Sefidmazgi, A. H. Mahdavi, and M. R. Wilkens. 2021. Low potassium diets with different levels of calcium in comparison with different anionic diets fed to prepartum dairy cows: Effects on sorting behaviour, total tract digestibility, energy metabolism, oxidative status and hormonal response. J. Anim. Physiol. Anim. Nutr. (Berl.) 105:1425. https://doi.org/10.1111/jpn.13438.

Rist, M. J., C. Muhle-Goll, B. Gorling, A. Bub, A. Heissler, B. Watzl, and B. Luy. 2013. Influence of freezing and storage procedures on human urine samples in NMR based metabolomics. Metabolites 3:243-258. https://doi.org/10.3390/metabo3020243.

Roche, J. R., S. Petch, and J. K. Kay. 2005. Manipulating the dietary cation-anion difference via drenching to early-lactation dairy cows grazing pasture. J. Dairy Sci. 88:264-276. https://doi.org/10 .3168/jds.S0022-0302(05)72684-9.

Santos, J. E. P., I. J. Lean, H. Golder, and E. Block. 2019. Meta-analysis of the effects of prepartum dietary cation-anion difference on performance and health of dairy cows. J. Dairy Sci. 102:2134-2154. https://doi.org/10.3168/jds.2018-14628.

Sokolov, V., A. VanderZaag, J. Habtewold, K. Dunfield, C. WagnerRiddle, J. J. Venkiteswaran, and R. Gordon. 2019. Greenhouse gas mitigation through dairy manure acidification. J. Environ. Qual. 48:1435-1443. https://doi.org/10.2134/jeq2018.10.0355

Tebbe, A. W., and W. P. Weiss. 2018. Evaluation of creatinine as a urine marker and factors affecting urinary excretion of magnesium by dairy cows. J. Dairy Sci. 101:5020-5032. https://doi.org/ 10.3168/jds.2017-14098.

Tucker, W. B., G. A. Harrison, and R. W. Hemken. 1988. Influence of dietary cation-anion balance on milk, blood, urine, and rumen 
fluid in lactating dairy cattle. J. Dairy Sci. 71:346-354. https://doi .org/10.3168/jds.S0022-0302(88)79563-6.

Tyrrell, H. F., and J. T. Reid. 1965. Prediction of the energy value of cow's milk. J. Dairy Sci. 48:1215-1223. https://doi.org/10.3168/ jds.S0022-0302(65)88430-2.

Urrutia, N. L., and K. J. Harvatine. 2017. Acetate dose-dependently stimulates milk fat synthesis in lactating dairy cows. J. Nutr. 147:763-769. https://doi.org/10.3945/jn.116.245001.

Vagnoni, D. B., and G. R. Oetzel. 1998. Effects of dietary cationanion difference on the acid-base status of dry cows. J. Dairy Sci. 81:1643-1652. https://doi.org/10.3168/jds.S0022-0302(98)75732 -7 .

Valadares, R. F., G. A. Broderick, S. C. Valadares Filho, and M. K. Clayton. 1999. Effect of replacing alfalfa silage with high moisture corn on ruminal protein synthesis estimated from excretion of total purine derivatives. J. Dairy Sci. 82:2686-2696. https://doi.org/10 .3168/jds.S0022-0302(99)75525-6.

Van Baale, M. J., J. M. Sargeant, D. P. Gnad, B. M. DeBey, K. F. Lechtenberg, and T. G. Nagaraja. 2004. Effect of forage or grain diets with or without monensin on ruminal persistence and fecal Escherichia coli O157:H7 in cattle. Appl. Environ. Microbiol. 70:5336-5342. https://doi.org/10.1128/AEM.70.9.5336-5342.2004.

Van Soest, P. J., J. B. Robertson, and B. A. Lewis. 1991. Methods for dietary fiber, neutral detergent fiber, and nonstarch polysaccharides in relation to animal nutrition. J. Dairy Sci. 74:3583-3597. https://doi.org/10.3168/jds.S0022-0302(91)78551-2.

van Zijderveld, S. M., W. J. J. Gerrits, J. A. Apajalahti, J. R. Newbold, J. Dijkstra, R. A. Leng, and H. B. Perdok. 2010. Nitrate and sulfate: Effective alternative hydrogen sinks for mitigation of ruminal methane production in sheep. J. Dairy Sci. 93:5856-5866. https://doi.org/10.3168/jds.2010-3281.

Weiss, W. P., L. B. Willett, N. R. St-Pierre, D. C. Borger, T. R. McKelvey, and D. J. Wyatt. 2009. Varying forage type, metabolizable protein concentration, and carbohydrate source affects manure excretion, manure ammonia, and nitrogen metabolism of dairy cows. J. Dairy Sci. 92:5607-5619. https://doi.org/10.3168/jds.2009-2248.
West, J. W., B. G. Mullinix, and T. G. Sandifer. 1991. Changing dietary electrolyte balance for dairy cows in cool and hot environments. J. Dairy Sci. 74:1662-1674. https://doi.org/10.3168/jds .S0022-0302(91)78329-X.

Wheeler, E. F., P. A. Topper, R. C. Brandt, N. E. Brown, A. Adviento-Borbe, R. S. Thomas, and G. A. Varga. 2011. Multiple-chamber instrumentation development for comparing gas fluxes from biological materials. Appl. Eng. Agric. 27:1049-1060. https://doi.org/ $10.13031 / 2013.40618$.

Zebeli, Q., S. M. Dunn, and B. N. Ametaj. 2011. Perturbations of plasma metabolites correlated with the rise of rumen endotoxin in dairy cows fed diets rich in easily degradable carbohydrates. J. Dairy Sci. 94:2374-2382. https://doi.org/10.3168/jds.2010-3860.

Zhang, N., Z. Bai, W. Winiwarter, S. Ledgard, J. Luo, J. Liu, Y. Guo, and L. Ma. 2019. Reducing ammonia emissions from dairy cattle production via cost-effective manure management techniques in China. Environ. Sci. Technol. 53:11840-11848. https://doi.org/10 .1021 /acs.est.9b04284.

Zimpel, R., M. B. Poindexter, A. Vieira-Neto, E. Block, C. D. Nelson, C. R. Staples, W. W. Thatcher, and J. E. P. Santos. 2018. Effect of dietary cation-anion different on acid-base status and dry matter intake in dry pregnant cows. J. Dairy Sci. 101:8461-8475. https:// doi.org/10.3168/jds.2018-14748.

\section{ORCIDS}

H. M. Zynda @ https://orcid.org/0000-0001-7039-7005

J. E. Copelin (ํ) https://orcid.org/0000-0003-0549-8189

W. P. Weiss ๑ https://orcid.org/0000-0003-3506-4672

F. Sun $\odot$ https://orcid.org/0000-0003-2540-4717

C. Lee 구 https://orcid.org/0000-0002-4522-1232 